ARTICLE

\title{
Pentaphosphaferrocene-mediated synthesis of asymmetric organo-phosphines starting from white phosphorus
}

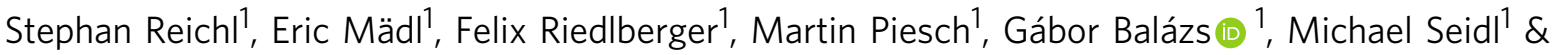 \\ Manfred Scheer ${ }^{1 \mathrm{~W}}$
}

The synthesis of phosphines is based on white phosphorus, which is usually converted to $\mathrm{PCl}_{3}$, to be afterwards substituted step by step in a non-atomic efficient manner. Herein, we describe an alternative efficient transition metal-mediated process to form asymmetrically substituted phosphines directly from white phosphorus $\left(P_{4}\right)$. Thereby, $P_{4}$ is converted to $\left[\mathrm{Cp}{ }^{\star} \mathrm{Fe}\left(\eta^{5}-\mathrm{P}_{5}\right)\right](\mathbf{1})\left(\mathrm{Cp}^{\star}=\eta^{5}-\mathrm{C}_{5}\left(\mathrm{CH}_{3}\right)_{5}\right)$ in which one of the phosphorus atoms is selectively functionalized to the 1,1-diorgano-substituted complex $\left[C p^{\star} F e\left(\eta^{4}-P_{5} R^{\prime} R^{\prime \prime}\right)\right](\mathbf{3})$. In a subsequent step, the phosphine $P R^{\prime} R^{\prime \prime} R^{\prime \prime \prime}\left(R^{\prime} \neq R^{\prime \prime} \neq R^{\prime \prime \prime}=\right.$ alky, aryl) (4) is released by reacting it with a nucleophile $R^{\prime \prime \prime} M(M=$ alkali metal) as racemates. The starting material $\mathbf{1}$ can be regenerated with $\mathrm{P}_{4}$ and can be reused in multiple reaction cycles without isolation of the intermediates, and only the phosphine is distilled off.

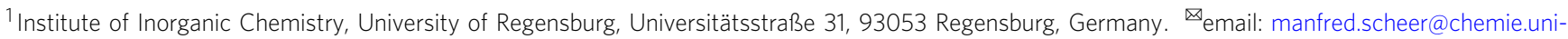
regensburg.de
} 
$\mathrm{T}$ he interest in organophosphorus compounds in life science, material science, and especially in ligand design for catalysis is an omnipresent topic ${ }^{1-5}$. Besides the use of phosphines as ligands ${ }^{4-6}$, the resulting complexes are widely used as catalysts in all areas of organic and organometallic chemistry ${ }^{7}$. One of the most prominent examples of a catalyst containing phosphines represents the Wilkinson's catalyst $\left[\mathrm{RhCl}\left(\mathrm{PPh}_{3}\right)\right]^{8}$, which catalyses, e.g. the hydrogenation of olefins. Over the last decades, a plethora of organophosphorus compounds was synthesised and investigated ${ }^{9-13}$. Although organophosphorus chemistry is a well-established area, the synthesis of asymmetrically substituted organophosphorus compounds is a crucial and challenging topic $\mathrm{c}^{2,6,14,15}$. Its importance in catalysis was awarded, e.g. with the Nobel prize ${ }^{16}$. The classical way to synthesise phosphines is via salt metathesis or hydrophosphination starting from $\mathrm{PCl}_{3}$ or $\mathrm{PH}_{3}$, respectively (Fig. 1) 12,13,17. In both cases, the targeted variation of the organic substituents is synthetically very challenging. Moreover, both $\mathrm{PCl}_{3}$ and $\mathrm{PH}_{3}$ are synthesised from $\mathrm{P}_{4}$ either by reaction with chlorine gas or by hydrolysis in basic or synthesized via hydrophosphination ${ }^{19}$. Interestingly, first attempts to synthesise organophosphorus compounds directly from phosphates have already been made by reduction with $\mathrm{HSiCl}_{3}$ followed by reaction with $\mathrm{RCl}^{20}$, although this development is still in its infancy ${ }^{21}$. Since both $\mathrm{Cl}_{2}$ and $\mathrm{PH}_{3}$ are toxic gases and because the synthesis of phosphines from $\mathrm{PCl}_{3}$ is associated with large (stoichiometric) amounts of side products, a more sustainable and atom-efficient process for a direct conversion of $\mathrm{P}_{4}$ into organophosphorus reagents is desirable. Besides these classical synthetic strategies, a few protocols have been developed for the direct synthesis of phosphines from $\mathrm{P}_{4}$. The first one of these protocols involves the generation of aryl radicals from aryl halides induced by an unsaturated Ti(III) complex ${ }^{22}$. The fundamental synthetic approach of all these protocols involves either an electrochemical approach ${ }^{23}$ or, more often, the generation of organo radicals from the corresponding halides induced by transition metal complexes $22,24-26$ as well as, quite recently, organotin-compounds ${ }^{27}$. These radical-promoted routes can be divided into stochiometric ${ }^{22,24,27}$ and/or (photo)catalytic approaches ${ }^{25,26}$.

The major drawback to all of these processes is that they do not lead to the formation of asymmetrically substituted phosphines, which are crucial for catalysis. In this report, we present a acidic aqueous media ${ }^{18}$. Note that, aryl phosphines cannot be

conceptually innovative strategy for a controlled and directed synthesis of symmetrically and asymmetrically substituted phosphines starting from $\mathrm{P}_{4}$ and carbon-centred nucleophiles and electrophiles by using $\left[\mathrm{Cp} * \mathrm{Fe}\left(\eta^{5}-\mathrm{P}_{5}\right)\right](\mathbf{1})\left(\mathrm{Cp}^{*}=\eta^{5}-\mathrm{C}_{5}\left(\mathrm{CH}_{3}\right)_{5}\right)$ as a $\mathrm{P}$-atom carrier.

\section{Results}

Synthesis and structural characterization of the monosubstituted complexes 2c-e. In our previous works, we were able to show that $\left[\mathrm{Cp} * \mathrm{Fe}\left(\eta^{5}-\mathrm{P}_{5}\right)\right]$ (1) readily reacts with maingroup nucleophiles such as $\mathrm{Me}_{3} \mathrm{SiCH}_{2}{ }^{-}$or $\mathrm{Me}_{2} \mathrm{~N}^{-}$via the formation of a $\mathrm{P}-\mathrm{C} / \mathrm{P}-\mathrm{N}$ bond ${ }^{28}$, leading to the complexes $\left[\mathrm{Cp} * \mathrm{Fe}\left(\eta^{4}-\mathrm{P}_{5} \mathrm{R}^{\prime}\right)\right]^{-}\left(\mathrm{R}^{\prime}=\mathrm{CH}_{2} \mathrm{SiMe}_{3}(\mathbf{2 a}), \mathrm{NMe}_{2}(\mathbf{2 b})\right)$. However, we found now that the nucleophile used can be freely varied, and basically any alkali metal organyl can be used (Fig. 2). The reaction of $\left[\mathrm{Cp} * \mathrm{Fe}\left(\eta^{5}-\mathrm{P}_{5}\right)\right]$ (1) with $\mathrm{MeLi},{ }^{t} \mathrm{BuLi}$ and $\mathrm{PhLi}$, respectively, at $-80^{\circ} \mathrm{C}$ leads to an immediate colour change from green to brown. After workup, the complexes $\left[\mathrm{Li}(\mathrm{dme})_{3}\right]$ $\left[\mathrm{Cp} * \mathrm{Fe}\left(\eta^{4}-\mathrm{P}_{5} \mathrm{Me}\right)\right] \quad(2 \mathrm{c}), \quad\left[\mathrm{Li}(12 \mathrm{c} 4)_{2}\right]\left[\mathrm{Cp} * \mathrm{Fe}\left(\eta^{4}-\mathrm{P}_{5}{ }^{t} \mathrm{Bu}\right)\right] \quad(\mathbf{2 d})$, $[\mathrm{Li}(12 \mathrm{c} 4)(\mathrm{thf})]\left[\mathrm{Cp} * \mathrm{Fe}\left(\eta^{4}-\mathrm{P}_{5} \mathrm{Ph}\right)\right](2 \mathrm{e})$ can be isolated in crystalline yields of $84 \%, 86 \%$ and $75 \%$, respectively.

The single-crystal X-ray structure analysis of $\mathbf{2}$ shows anionic complexes with a folded $\mathrm{P}_{5} \mathrm{R}^{\prime}$-ligand in an envelope conformation (Fig. 3, Supplementary Figs. 40-43). The four coordinating phosphorus atoms of the $\mathrm{P}_{5} \mathrm{R}^{\prime}$ ligand build a nearly square planar $\mathrm{P}_{4}$ unit which coordinates symmetrically to the $\mathrm{Cp}^{*} \mathrm{Fe}$ fragment. The $\mathrm{P} 1$ atom to which the organic group is attached (P1-C1 bond length of $1.849(2) \AA$ (2c), $1.898(3) \AA$ (2d) and 1.841(3) $\AA$ (2e)) deviates from this plane. All P2-P5 bond lengths $(1.993(13)-2.1575(10) \AA))$ are in the range between a single and a double bond ${ }^{29,30}$.

Reactivity of 2 towards electrophiles. The presence of the negative charge renders the compounds 2 nucleophilic, which is why they can be quenched with electrophiles such as alkyl or aryl halides. Thus, the compounds 2 were treated with alkyl halides $\mathrm{R}^{\prime \prime}$ $\mathrm{X}\left(\mathrm{R}^{\prime \prime}=\mathrm{Me},{ }^{i} \mathrm{Pr} ; \mathrm{X}=\mathrm{Br}, \mathrm{I}\right)$ as common carbon-centred electrophiles. Indeed, the neutral organo-substituted polyphosphorus complexes $\left[\mathrm{Cp} * \mathrm{Fe}\left(\eta^{4}-\mathrm{P}_{5} \mathrm{R}^{\prime} \mathrm{R}^{\prime \prime}\right)\right]$ (3; Fig. 2) were obtained in almost quantitative yields according to ${ }^{31} \mathrm{P}$ NMR spectroscopy. The isolated compounds $\mathbf{2}$ and $\mathbf{3}$ were characterized by NMR spectroscopy (Supplementary Figs. 1-9; 17-26), mass

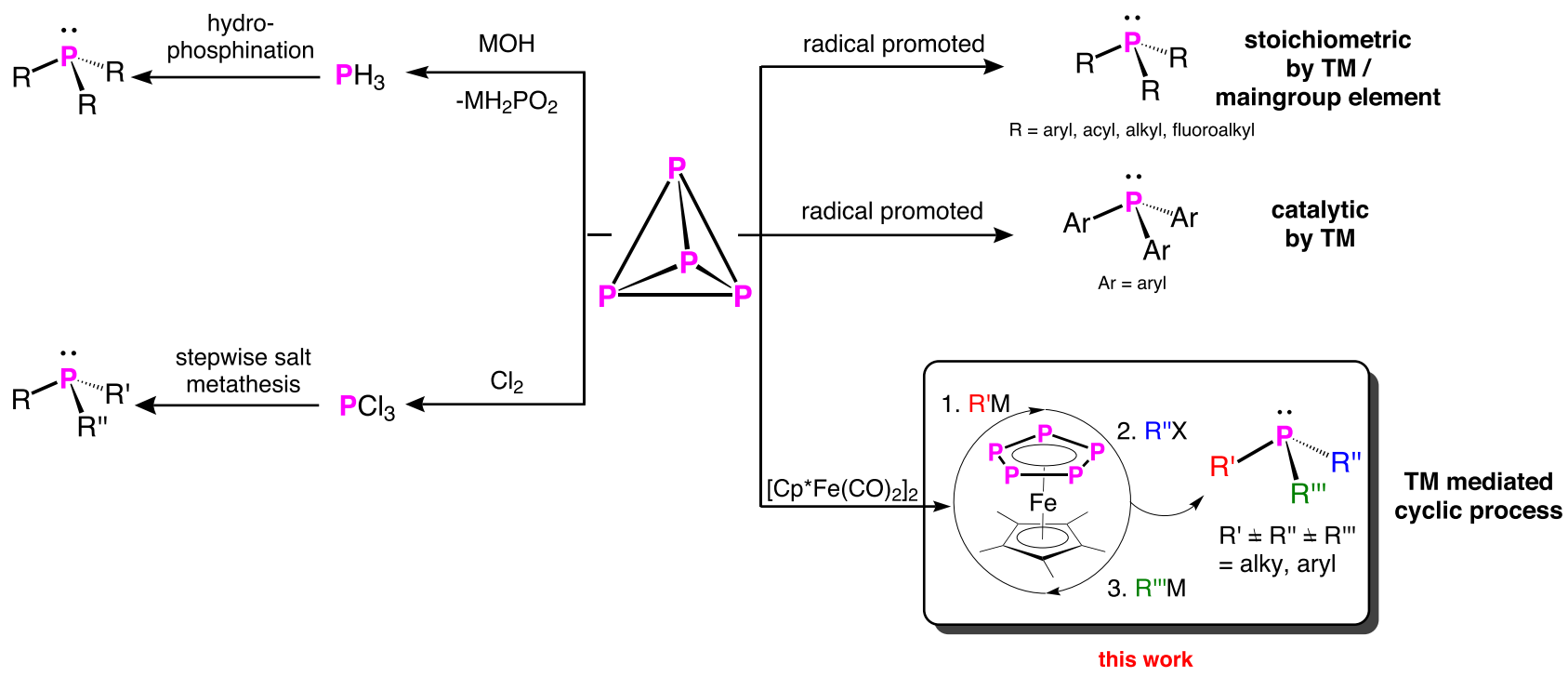

Fig. 1 Different approaches for the synthesis of ternary phosphines. Left: conventional way, hydrophosphination and salt metathesis. Right: Radical promoted, stochiometric and catalytic, as well as the 'semi-catalytic' transition metal (TM) mediated synthesis of ternary phosphines. 


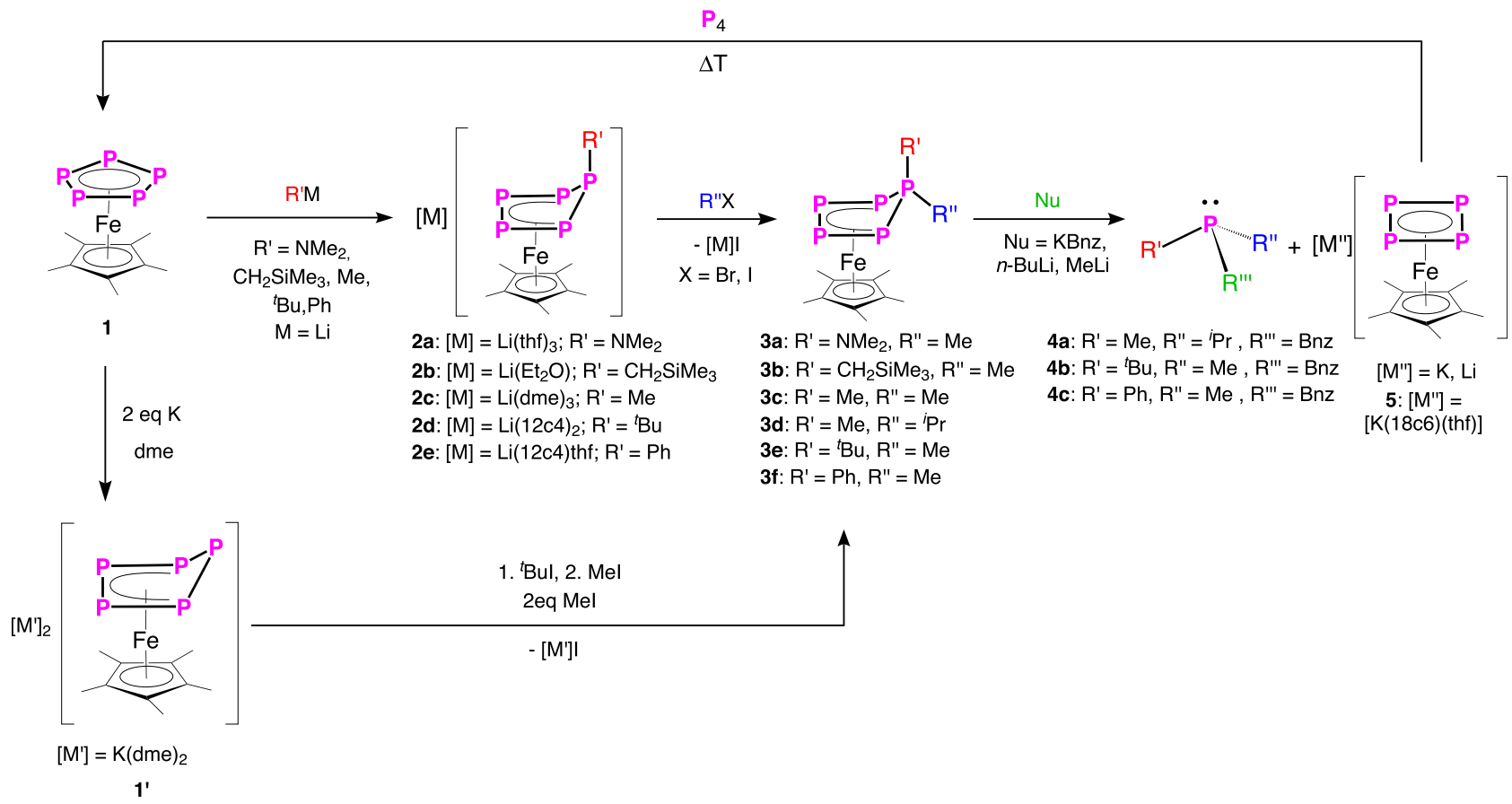

Fig. 2 Synthesis of asymmetric phosphines 4, via successive nucleophilic, electrophilic, nucleophilic attack. Synthesis of the anionic precursor complexes $\mathbf{2}$ by nucleophilic attack; electrophilic quenching of $\mathbf{2}$ (synthesis of $\mathbf{3}$ ); asymmetric phosphine abstraction by nucleophiles (synthesis of $\mathbf{4}, \mathbf{5}$ ); regeneration of $\mathbf{1}$ by thermolysis with $\mathrm{P}_{4}$; alternative synthesis of $\mathbf{3}$ by electrophilic quenching of $\mathbf{1}^{\prime}$.

spectrometry, elemental analysis, and single-crystal XRD (Fig. 3, Supplementary Figs. 40-50). The latter shows that, in 3, the folded $\eta^{4}-\mathrm{P}_{5}$ unit remains intact and the introduced electrophile is attached to the phosphorus atom, which bears the first organosubstituent (former nucleophiles; R', Fig. 3), leading to a 1,1substitution pattern with a P1-C2 bond length (1.785(5)-1.922(11) $)$ ) corresponding to single bonds ${ }^{29}$. The functionalized phosphorus atoms P1 carry two organic substituents and possess a phosphonium ion-like character (Fig. 4). Of particular interest are the compounds $\mathbf{3 a} \mathbf{a} \mathbf{b}$ and $\mathbf{3 f}$ since they represent precursors for quite rare asymmetrically substituted organo-phosphine derivatives 2,31 . Due to the large diversity of alkali metal organyls and electrophilic organo halides, the shown procedure gives access to the synthesis of a plethora of complexes of type 3. An alternative way for the synthesis of $\mathbf{3}$ is the reaction of the doubly reduced derivative of $\mathbf{1},\left[\mathrm{K}(\mathrm{dme})_{2}\right]_{2}\left[\mathrm{Cp} * \mathrm{Fe}\left(\eta^{4}-\mathrm{P}_{5}\right)\right]$ $\left(\mathbf{1}^{\prime}\right)^{32}$, with alkyl halides. This was demonstrated by the synthesis of $3 \mathrm{c}$ and $3 \mathbf{e}$, which proceeds according to ${ }^{31} \mathrm{P}$ NMR in a quantitative manner (Supplementary Figs. 69, S70) and shows that possible limitations of organolithium reagents needed in the former procedure can be avoided. The reaction of $\mathbf{1}^{\prime}$ with two equivalents of MeI leads smoothly to $3 \mathrm{c}$, while the addition of one equivalent of ${ }^{t} \mathrm{BuI}$ followed by the addition of one equivalent of MeI leads to the formation of $\mathbf{3 e}$ (Fig. 2). In the ${ }^{31} \mathrm{P}$ NMR spectra of 2 (Supplementary Figs. 17-20) and $\mathbf{3}$ (Supplementary Figs. 21-26), $\mathrm{AMM}^{\prime} \mathrm{XX}^{\prime}$ spin systems were detected from which the coupling constants were obtained by simulations (Supplementary Tables 1-10). The related signals of the phosphorus atoms P1 of $\mathbf{3}$ are downfield shifted compared to 2 . This is in agreement with the phosphonium-like nature of the phosphorus atom $\mathrm{P} 1$ in 3.

Synthesis of (a)symmetric phosphines-reactivity of 3 towards nucleophiles. The electrostatic potential surface of compound 3c (B3LYP/def2-TZVPP level of theory; Fig. 4) shows a rather localized positive potential on the phosphorus atom bearing the organo- substituents (P1). Therefore, the attack of a nucleophile is expected to occur at the position P1. Indeed, the reaction of $\mathbf{3 d}$ with benzyl potassium lead to the formation of the asymmetrically substituted phosphine $\mathrm{PMe}^{i} \mathrm{PrBnz}$ (4a) in $82 \%$ yield (Supplementary Fig. 61) and the anion $\left[\mathrm{Cp} * \mathrm{Fe}\left(\eta^{4}-\mathrm{P}_{4}\right)\right]^{-}$(Supplementary Fig. 55). This strategy can be extended for the synthesis of a series of asymmetric phosphines, with $\mathrm{PR}^{\prime} \mathrm{R}^{\prime \prime} \mathrm{R}^{\prime \prime \prime}\left(\mathbf{4 a - c}\left(\mathbf{a}: \mathrm{R}^{\prime}=\mathrm{Me}, \mathrm{R}^{\prime \prime}={ }^{i} \mathrm{Pr}, \mathrm{R}^{\prime \prime \prime}=\mathrm{Bnz}\right.\right.$; b: $\left.\mathrm{R}^{\prime}={ }^{t} \mathrm{Bu}, \mathrm{R}^{\prime \prime}=\mathrm{Me}, \mathrm{R}^{\prime \prime \prime}=\mathrm{Bnz} ; \mathrm{c}: \mathrm{R}^{\prime}=\mathrm{Ph}, \mathrm{R}^{\prime \prime}=\mathrm{Me}, \mathrm{R}^{\prime \prime \prime}=\mathrm{Bnz}\right)$ ) being isolated as air-sensitive viscous liquids in $82 \%$ (4a), 55\% (4b), $80 \%$ (4c) yields, respectively. The identity of the phosphine was proven by NMR spectroscopy and, after oxidation with sulfur to the corresponding phosphine sulfides (Supplementary Figs. 10-16; 27-32; 34-39), also by single-crystal X-ray diffraction analysis (Fig. 3, Supplementary Figs. 51-54). Furthermore, by changing the nucleophile to $\mathrm{MeLi}$ and ${ }^{n} \mathrm{BuLi}$, the corresponding phosphines $\mathrm{PMe}_{3}$ and $\mathrm{PMe}_{2}{ }^{n} \mathrm{Bu}$ can be obtained in the reaction with $3 \mathrm{c}$ (Supplementary Figs. 56, 57). The latter is less selective, $\mathrm{PMe}_{3}$, however, can be synthesized via this route in $84 \%$ yield (according to NMR).

To identify potential intermediates in the reaction of 3 with nucleophiles, the reaction of $3 \mathrm{c}$ with $\mathrm{MeLi}$ at $-80^{\circ} \mathrm{C}$ in THF- $\mathrm{d}_{8}$ was monitored by ${ }^{31} \mathrm{P}\left\{{ }^{1} \mathrm{H}\right\}$ NMR spectroscopy at this temperature. The ${ }^{31} \mathrm{P}$ NMR spectrum clearly shows the full conversion of 3 and quantitative formation of 4 and 5 (Fig. 5A, Supplementary Fig. 68). These very fast reactions agree with the results of the DFT calculations which show a very low activation barrier for this process (Figs. 5B, S71).

The other product of the reaction of $\mathbf{3}$ with nucleophiles, i.e. $[\mathrm{M}]\left[\mathrm{Cp} * \mathrm{Fe}\left(\eta^{4}-\mathrm{P}_{4}\right)\right]\left(\mathrm{M}=\mathrm{K}(\mathrm{dme})_{3} ; 5\right)$ is a rare representative of the anionic complexes with a cyclo- $\mathrm{P}_{4}$ ligand as an end-deck ${ }^{33-35}$. The addition of 18-crown- 6 considerably increases its stability and 5 can be isolated in $81 \%$ crystalline yield, which is a major improvement over the previously reported complex [K(18c6)] $\left[\mathrm{Cp}{ }^{\mathrm{Ar}} \mathrm{Fe}\left(\eta^{4}-\mathrm{P}_{4}\right)\right]^{-}\left(\mathrm{Cp}^{\mathrm{Ar}}=\mathrm{C}_{5}\left(\mathrm{C}_{6} \mathrm{H}_{4}-4-\mathrm{Et}\right)_{5}\right)$ obtained in $4 \%$ yield ${ }^{33}$. In the solid state, the anion $\left[\mathrm{Cp}^{*} \mathrm{Fe}\left(\eta^{4}-\mathrm{P}_{4}\right)\right]^{-}$(Fig. 3, Supplementary Fig. 55) features a square planar cyclo- $\mathrm{P}_{4}$ ligand with bond lengths between $2.1666(13)$ and 2.175(13) $\AA$, which are in the range between a single ${ }^{29}$ and a double bond ${ }^{30}$. In the 

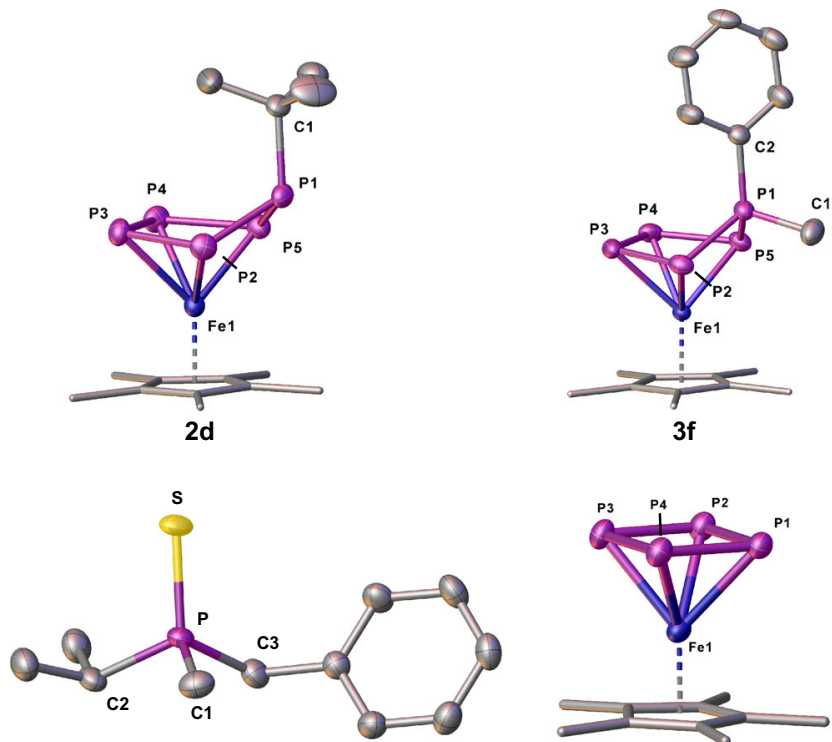

$4 a^{\prime}$

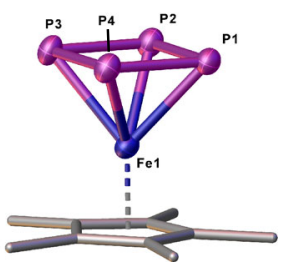

5

Fig. 3 Molecular structures of the anions in $2 d, 5$ and of the neutral complexes $\mathbf{3 f}, \mathbf{4} a^{\prime}$ with thermal ellipsoids at $\mathbf{5 0} \%$ probability level. Cations and hydrogen atoms are omitted for clarity. The $\mathrm{Cp}^{\star}$ ligands are drawn in the wire frame model.

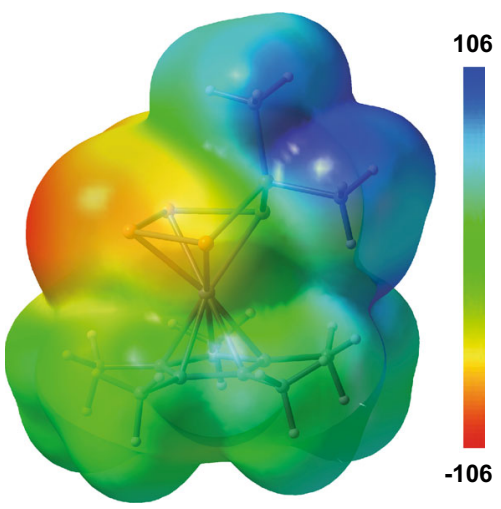

Fig. 4 Electrostatic potential mapped on electron density

(isovalue $=\mathbf{0 . 0 0 1}$ ) for $\mathbf{3 c}$. Colour code (blue $=$ positive, red $=$ negative) in $\mathrm{kJ} \cdot \mathrm{mol}^{-1}$.

${ }^{31} \mathrm{P}\left\{{ }^{1} \mathrm{H}\right\}$ NMR spectrum of $\mathbf{5}$, a singlet is observed at $118.9 \mathrm{ppm}$ (Supplementary Fig. 39). The lithium derivative of $\mathbf{5}$ can be detected in all reactions of $\mathbf{3 b}$-e with organolithium reagents but decomposes partly over time in solution.

Formation of phosphines and regeneration of the carrier platform $\left[\mathrm{Cp} * \mathrm{Fe}\left(\eta^{5}-\mathrm{P}_{5}\right)\right](1)$ in a 'semi-catalytic' cyclic process. The phosphines generated in the reaction of $\mathbf{3}$ with nucleophiles can be easily isolated either by extraction with $n$-hexane ( 5 is not soluble in $n$-hexane) or, in the case of volatile phosphines, by condensation. That is why we were interested in designing a closed-cycle-process for the generation of phosphines in which $\mathbf{1}$ represents the platform for the phosphorus atom transfer. To close the circle, 5 was reacted with one equivalent of $\mathrm{P}_{4}$ with 1 being formed in almost quantitative yield, among $\mathrm{KP}_{5}$, which partly decomposes to polyphosphides ${ }^{36}$ (Supplementary Fig. 65). After workup, 1 can be isolated in $81 \%$ crystalline yield (Fig. 6). If required, $\mathrm{KP}_{5}$ can be transformed into the corresponding pentaphosphaferrocene by reacting with $[\mathrm{Cp} * \mathrm{FeBr}]_{2}{ }^{37}$ to increase the

A
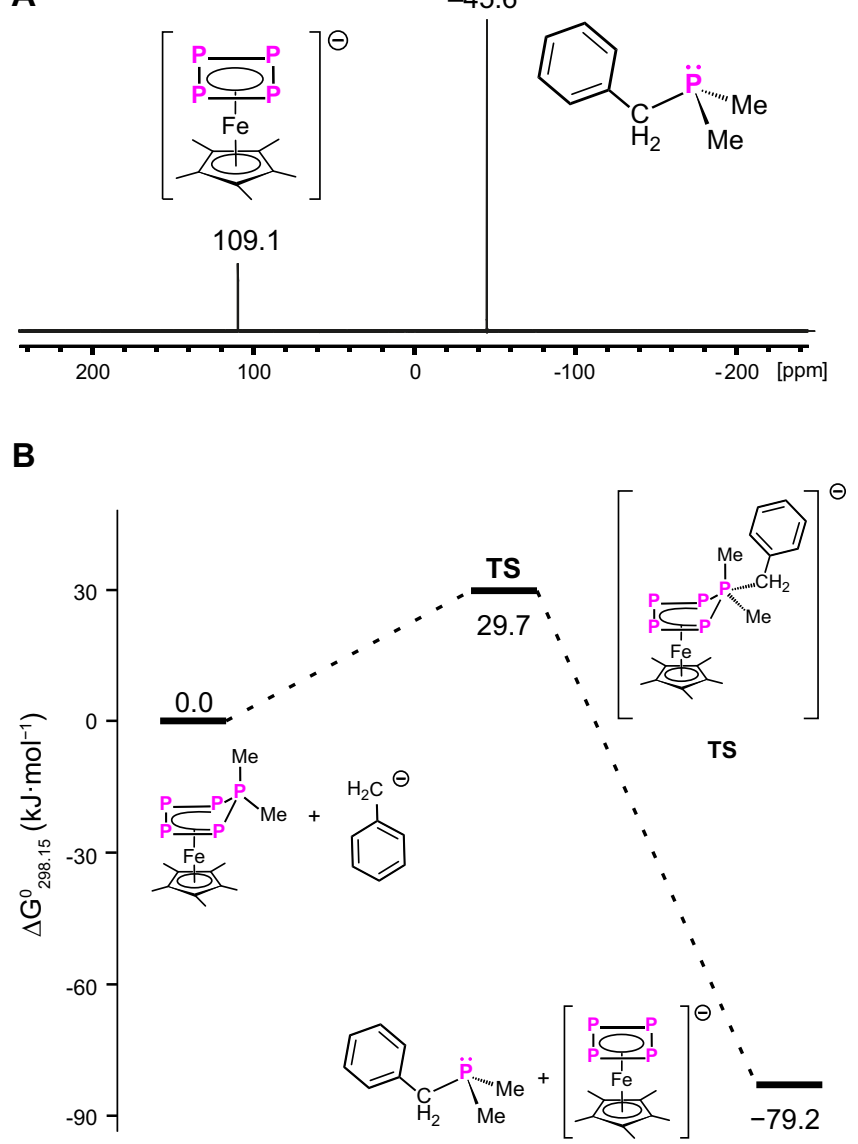

Fig. 5 Identification of the reaction pathway of phosphine abstraction. A Experimental ${ }^{31} \mathrm{P}\left\{{ }^{1} \mathrm{H}\right\} \mathrm{NMR}\left(242.90 \mathrm{MHz}, \mathrm{THF}-\mathrm{d}_{8}\right)$ spectrum of the crude reaction solution (low-temperature reaction) of $\mathbf{3 c}$ with $\mathrm{KBnz}$ at $180 \mathrm{~K}$. B Gibbs free energy profile of the reaction of $\mathbf{3 c}$ with $\mathrm{KBnz}$, calculated at the B3LYP-D3(BJ)/def2-TZVPP (PCM = THF) level of theory.

atom efficiency of this process. Moreover, it is possible to perform a larger scale synthesis of the phosphines in a one-pot reaction to easily reuse $\mathbf{1}$ and to avoid the workup of the reaction solution. In a one-pot reaction, compound $\mathbf{1}$ was dissolved in 2,5,8,11,14pentaoxapentadecane (tetraglyme) and stoichiometric amounts of $\mathrm{MeLi}$ and $\mathrm{MeI}$ were successively added at r.t. with $5 \mathrm{~min}$ stirring in between (Fig. 6, steps I and II). Subsequently, the solution was cooled to $-30^{\circ} \mathrm{C}$ and one equivalent of $\mathrm{KBnz}$ in tetraglyme was added (Fig. 6, step III). The cooling bath was removed, the formed phosphine $\mathrm{PMe}_{2} \mathrm{Bnz}$ was distilled off under reduced pressure $\left(1 \times 10^{-3} \mathrm{mbar}, 55^{\circ} \mathrm{C}\right)$ and was obtained in $87 \%$ yield (Fig. 6, step III, Supplementary Fig. 67). To the remaining solution, one equivalent of white phosphorus was added and heated under reflux for $1 \mathrm{~h}$ at $275^{\circ} \mathrm{C}(\mathrm{IV})$. The ${ }^{31} \mathrm{P}\left\{{ }^{1} \mathrm{H}\right\}$ NMR spectrum (Supplementary Fig. 63) shows the almost quantitative regeneration of 1 . The same protocol was repeated two more times on the same reaction solution (see Supplementary Fig. 64). The phosphine $\mathrm{PMe}_{2} \mathrm{Bnz}$ was isolated in $82-67 \%$ yield (overall isolated yield $79 \%$, see Supplementary Fig. 67, Supplementary Table 40). After these three cycles, 1 can be isolated from the reaction solution in 69\% yield (Supplementary Fig. 66), indicating that this process could be carried on for many more cycles.

In summary, the polyphosphorus compound [Cp* $\left.\mathrm{Fe}\left(\eta^{5}-\mathrm{P}_{5}\right)\right]$ (1) can be used as a recyclable platform for the targeted synthesis of symmetric or asymmetric phosphines, via a sequence of nucleophilic-electrophilic-nucleophilic reactions, directly from white phosphorus, avoiding the use of intermediate products 


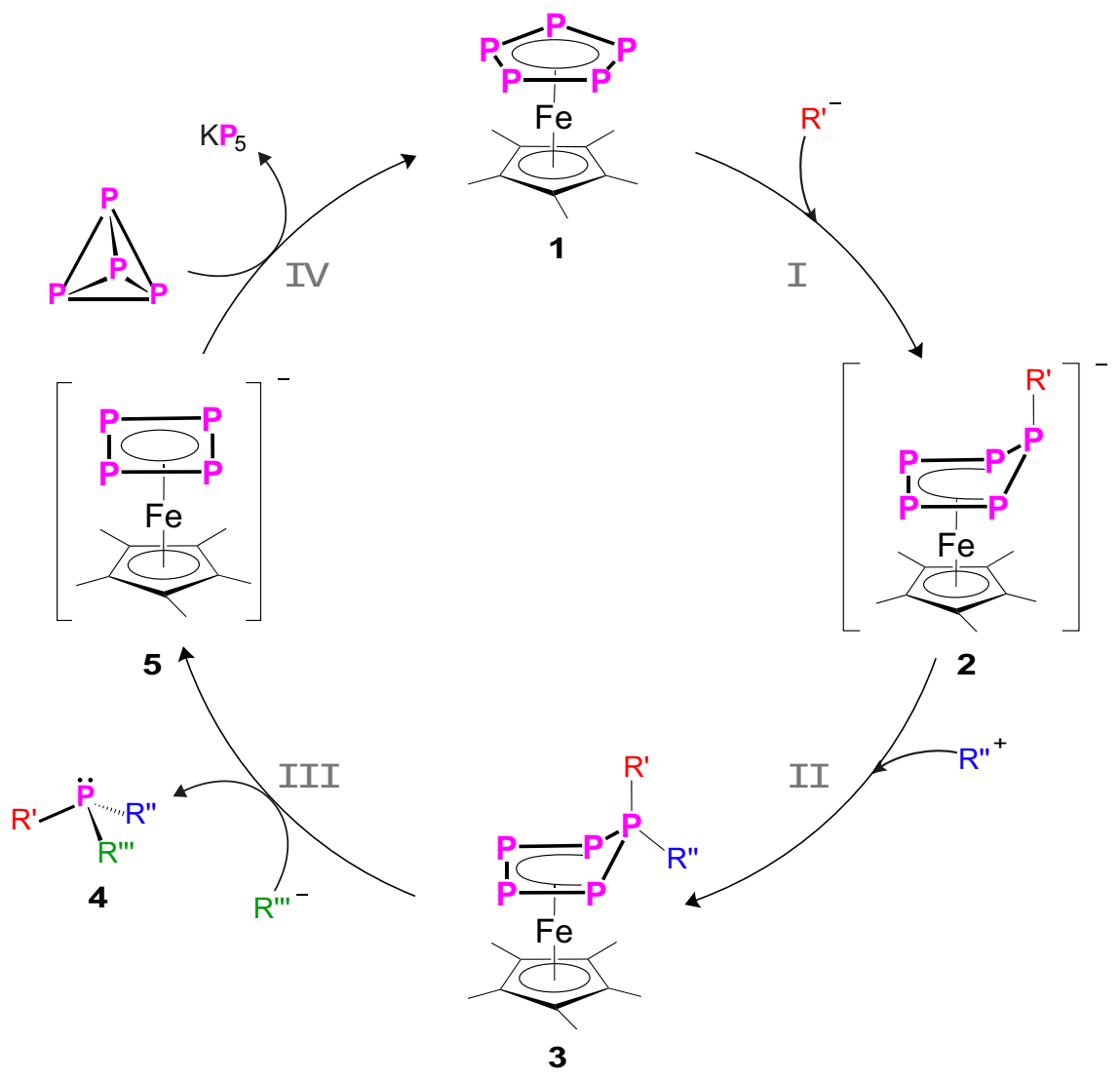

Fig. 6 'Semi-catalytic' cycle for the synthesis of asymmetric phosphines. One-pot reaction of $\left[C p^{\star} F e\left(\eta^{5}-P_{5}\right)\right](\mathbf{1})$ with MeLi $\left(I, R^{\prime}=M e\right)$, quenching with Mel (II, $\left.R^{\prime \prime}=\mathrm{Me}\right)$, reaction with $\mathrm{KBnz}\left(\mathrm{III}, \mathrm{R}^{\prime \prime \prime}=\mathrm{Bnz}\right)$ and subsequent thermolysis with white phosphorus (IV).

such as $\mathrm{PCl}_{3}$ or $\mathrm{PH}_{3}$. With this modular system, asymmetric phosphines are obtained in high yields in significant preparative scales and $\mathbf{1}$ can be regenerated and reused in a 'semi-catalytic' cyclic process, which can be run for several cycles in a one-pot reaction. The presented results pave the way for a selective and easy synthetic route to asymmetric and (in future work potential) chiral phosphines based on white phosphorus. This conceptual innovative approach avoids radicals and is not limited to aryl or alkyl substituents, but phosphines with a variety of different substitution patterns are now accessible in high yields by a very simple approach.

\section{Methods}

General methods. All manipulations were carried out under an inert atmosphere of dried argon using standard Schlenk and glove box techniques. 1,2-dimethoxyethane (DME), 2,5,8,11-tetraoxadodecane (triglyme) and 2,5,8,11,14-pentaoxapentadecane (tetraglyme) were dried and deoxygenated by distillation under argon atmosphere from sodium (DME) or calcium hydride. All other solvents were dried using a MB SPS-800 device of the company MBRAUN and stored over molecular sieve. NMR spectra were recorded on a Bruker Avance III 400/600 MHz NMR spectrometer. Chemical shifts were measured at ambient temperature and are given in ppm; they are referenced to TMS for ${ }^{1} \mathrm{H}$ and $85 \% \mathrm{H}_{3} \mathrm{PO}_{4}$ for ${ }^{31} \mathrm{P}$ as external standard. Signal multiplicities are described using common abbreviations: $\mathrm{s}$ (singlet), d (doublet), $\mathrm{t}$ (triplet), q (quartet), quint (quintet), $\mathrm{m}$ (multiplet) and br (broad). LIFDI-/FD-/EI-MS spectra (LIFDI = liquid injection field desorption ionization, $\mathrm{FD}=$ field desorption, $\mathrm{EI}=$ electron ionization) were measured on a JEOL AccuTOF GCX. ESI-MS spectra (ESI = electrospray ionization) were measured on an Agilent Q-TOF 6540 UHD. Elemental analysis (CHN) was determined using a Vario micro cube instrument. A glass stirring bar was used in reactions with potassium benzyl. DFT calculations were carried out using the Gaussian 16 program $^{38}$. The geometries were optimised using the B3LYP ${ }^{39-42}$ functional together with the def2-TZVPP basis set ${ }^{43}$. Solvation effects were incorporated via the polarizable continuum model ${ }^{44}$ using the dielectric constant of THF. Dispersion effects were incorporated via Grimme's correction with Becke-Johnson damping 45 .
Unless otherwise stated, all other chemicals were obtained from commercial sources. Crystals suitable for single-crystal X-ray diffraction analysis were obtained as described in the corresponding synthetic protocols below. The diffraction data were collected either on a Gemini Ultra diffractometer equipped with an Atlas ${ }^{\mathrm{S} 2} \mathrm{CCD}$ detector and with a fine-focus sealed $\mathrm{Cu}-\mathrm{K}_{\alpha} \mathrm{X}$-ray tube, on a XtaLAB Synergy R, DW system diffractometer equipped with a HyPix-Arc 150 detector and a rotating-anode $\mathrm{Cu}-\mathrm{K}_{\alpha} \mathrm{X}$-ray tube or a GV50 diffractometer equipped with a Titan ${ }^{\mathrm{S}} \mathrm{CCD}$ detector and a micro-focus $\mathrm{Cu}-\mathrm{K}_{\alpha} \mathrm{X}$-ray tube. Data collection and reduction were performed with CrysAlisPro software package. The structures were solved with Olex $2^{46}$, using ShelXT ${ }^{47}$ and a least-square refinement on F2 was carried out with ShelXL ${ }^{48}$. All non-hydrogen atoms were refined anisotropically. Hydrogen atoms at the carbon atoms were located in idealized positions and refined with isotropic displacement parameters according to the riding model.

The images of the molecular structures were made using Olex $2^{46}$.

\section{Synthetic protocols}

Synthesis of $\left[C p^{*} F e\left(\eta^{5}-P_{5}\right)\right](1)^{49}$. The complex $\left[\mathrm{Cp} * \mathrm{Fe}(\mathrm{CO})_{2}\right]_{2}(10 \mathrm{~g}, 20.0 \mathrm{mmol})$ and white phosphorus $(7 \mathrm{~g}, 56.5 \mathrm{mmol})$ are dissolved in 1,3-diisopropylbenzene $(500 \mathrm{ml})$ and heated to reflux for $7 \mathrm{~h}$. The solvent was removed in vacuo. The residue was dissolved in dichloromethane, silica was added and the solvent was removed under reduced pressure. The preabsorbed reaction mixture was purified via column chromatography $\left(\mathrm{SiO}_{2}\right.$, hexane, $\left.10 \times 3 \mathrm{~cm}\right)$. Using $n$-hexane, compound $\mathbf{1}(12.3 \mathrm{~g}, 35.6 \mathrm{mmol}, 89 \%)$ can be eluted as a dark green fraction. Complex $\mathbf{1}$ can be obtained after 1 day from a concentrated solution stored at $-30^{\circ} \mathrm{C}$ as green needles.

Synthesis of $\left[K(d m e)_{2}\right]_{2}\left[C p^{*} F e\left(\eta^{4}-P_{5}\right)\right]\left(\mathbf{1}^{\prime}\right)^{32}$. A solution of $1(0.4 \mathrm{~g}, 1.16 \mathrm{mmol}$, $1 \mathrm{eq})$ in DME $(30 \mathrm{ml})$ was added to potassium $(0.136 \mathrm{~g}, 3.47 \mathrm{mmol}, 3 \mathrm{eq})$. The solution was stirred at ambient temperature for $4 \mathrm{~h}$. The solution was filtered; the product was extracted from an insoluble residue with DME $(70 \mathrm{ml})$. The volume of the combined solution was reduced to ca. $30 \mathrm{ml}$ and $\mathrm{Et}_{2} \mathrm{O}(30 \mathrm{ml})$ was added. The suspension was stirred overnight and the product was collected on a frit, washed with $\mathrm{Et}_{2} \mathrm{O}(30 \mathrm{ml})$ and dried in vacuum to give $\mathbf{1}^{\prime}(0.74 \mathrm{~g}, 0.95 \mathrm{mmol})$ as dark brown-green powder.

Synthesis of $\left[\mathrm{Li}(\mathrm{thf})_{3}\right]\left[\mathrm{Cp} \mathrm{p}^{*} \mathrm{Fe}\left(\eta^{4}-\mathrm{P}_{5} \mathrm{NMe}_{2}\right)\right](2 \mathrm{a})^{28}$. To a solution of $\mathbf{1}(176 \mathrm{mg}$, $0.51 \mathrm{mmol})$ in $5 \mathrm{~mL}$ THF a solution of $\mathrm{LiNMe}_{2}(26 \mathrm{mg}, 0.51 \mathrm{mmol})$ was added at 
$-35^{\circ} \mathrm{C}$. The colour of the solution turned immediately from green to brown. The reaction mixture was stirred over $20 \mathrm{~h}$, the solvent was concentrated to $3 \mathrm{~mL}$ and finally layered with $n$-hexane. After 4 days on room temperature light brown square-shaped crystals of $2 \mathrm{a}(150 \mathrm{mg}, 0.25 \mathrm{mmol}, 50 \%)$ were formed.

Synthesis of $\left[\mathrm{Li}(\mathrm{dme})_{3}\right]\left[\mathrm{Cp}^{*} \mathrm{Fe}\left(\eta^{4}-\mathrm{P}_{5} \mathrm{Me}\right)\right](\mathbf{2} \boldsymbol{b})^{49}$. To a solution of ((trimethylsilyl) methyl)lithium $(68 \mathrm{mg}, 0.72 \mathrm{mmol})$ in $\mathrm{Et}_{2} \mathrm{O}(5 \mathrm{~mL})$ at $-35^{\circ} \mathrm{C}$ was added a solution of $1(250 \mathrm{mg}, 0.72 \mathrm{mmol})$ in $\mathrm{Et}_{2} \mathrm{O}(15 \mathrm{~mL})$. Immediate colour change was observed. The solution was slowly warmed up to ambient temperature and volume of the reaction mixture was reduced to ca. $15 \mathrm{~mL}$ and layered with $n$-hexane $(20 \mathrm{~mL})$. Black crystals of $2 \mathbf{b}(342 \mathrm{mg}, 0.66 \mathrm{mmol}, 92 \%)$ were formed after 2 days at $0{ }^{\circ} \mathrm{C}$

Synthesis of $\left[\mathrm{Li}(\mathrm{dme})_{3}\right]\left[\mathrm{C} \mathrm{P}^{*} \mathrm{Fe}\left(\eta^{4}-\mathrm{P}_{5} \mathrm{Me}\right)\right](2 \mathrm{c})$. To a solution of $138.0 \mathrm{mg}(0.4 \mathrm{mmol}$, 1 eq) of 1 in DME at $-60^{\circ} \mathrm{C}$, a 1.6 molar solution of $\mathrm{MeLi}(0.4 \mathrm{mmol}, 0.27 \mathrm{~mL}, 1 \mathrm{eq})$ in $\mathrm{Et}_{2} \mathrm{O}$ (diethylether) was added and an immediate colour change to brown could be observed. The solution was stirred for $4 \mathrm{~h}$, the solvent was reduced to $5 \mathrm{~mL}$ and layered with $n$-hexane $(25 \mathrm{~mL})$. [ $\left.\mathrm{Li}(\mathrm{dme})_{3}\right]\left[\mathrm{Cp} * \mathrm{Fe}\left(\eta^{4}-\mathrm{P}_{5} \mathrm{Me}\right)\right](2 \mathrm{c})$ was isolated as black truncated prisms. Yield: $216.0 \mathrm{mg}(0.34 \mathrm{mmol}, 83 \%) .{ }^{1} \mathrm{H}$ NMR (thf- $\left.\mathrm{d}_{8}, 293 \mathrm{~K}\right)$ : $\delta[\mathrm{ppm}]=1.49\left(\mathrm{~s}, 15 \mathrm{H}, \mathrm{C}_{5}\left(\mathrm{CH}_{3}\right)_{5}\right), 0.39\left(\mathrm{~m}, 3 \mathrm{H},-\left(\mathrm{CH}_{3}\right)\right),{ }^{31} \mathrm{P}\left\{{ }^{1} \mathrm{H}\right\} \mathrm{NMR}\left(\right.$ thf- $\mathrm{d}_{3}$, $293 \mathrm{~K}): \delta[\mathrm{ppm}]=71.3\left(\mathrm{~m}, 1 \mathrm{P}, \mathrm{P}_{\mathrm{A}}^{-}\right), 13.7\left(\mathrm{~m}, 2 \mathrm{P}, \mathrm{P}_{\mathrm{M}, \mathrm{M}^{\prime}}\right),-71.5\left(\mathrm{~m}, 2 \mathrm{P}, \mathrm{P}_{\mathrm{X}, \mathrm{x}^{\prime}}\right) .{ }^{31} \mathrm{P}$ NMR (thf- $\left.\mathrm{d}_{8}, 293 \mathrm{~K}\right): \delta[\mathrm{ppm}]=71.3\left(\mathrm{~m}, 1 \mathrm{P}, \mathrm{P}_{\mathrm{A}}\right), 13.7\left(\mathrm{~m}, 2 \mathrm{P}, \mathrm{P}_{\mathrm{M} . \mathrm{M}^{\prime}}\right),-71.5(\mathrm{~m}$, $2 \mathrm{P}, \mathrm{P}_{\mathrm{x}, \mathrm{x}^{\prime}}$ ); For coupling constants, see Supplementary Tables 1-10. ESI-MS (anion, DME): $m / z=360.95\left(6 \%,[\mathrm{M}]^{-}\right), 376.94\left(8 \%,\left[\mathrm{MO}^{-}\right), 392.93\left(100 \%,\left[\mathrm{MO}_{2}\right]^{-}\right)\right.$; analysis (calcd., found for $\left.\mathrm{C}_{23} \mathrm{H}_{48} \mathrm{FeLiO}_{6} \mathrm{P}_{5}\right)$ : $\mathrm{C}(43.28,42.84), \mathrm{H}(7.58,7.42)$.

Synthesis of $\left[\mathrm{Li}(12 \mathrm{c} 4)_{2}\right]\left[\mathrm{C} p^{*} \mathrm{Fe}\left(\eta^{4}-P_{5}{ }^{\mathrm{t}} \mathrm{Bu}\right)\right]$ (2d). Compound $1(0.2 \mathrm{mmol}, 69.2 \mathrm{mg}$, 1 eq) was dissolved in $10 \mathrm{~mL}$ THF (tetrahydrofuran) and cooled to $-80^{\circ} \mathrm{C}$. A 1.7 molar solution of ${ }^{t} \mathrm{BuLi}(0.2 \mathrm{mmol}, 0.12 \mathrm{~mL}, 1 \mathrm{eq})$ in $n$-pentane was added dropwise. An immediate change in colour from green to brown occurred. The mixture was allowed to stir overnight and reach room temperature. 12-crown-4 (12c4) $(0.4 \mathrm{mmol}, 0.07 \mathrm{~mL}, 2 \mathrm{eq})$ was added to the brown solution and stirred for $30 \mathrm{~min}$ at room temperature. The solvent was removed under reduced pressure. The brown residue was washed with $2 \times 10 \mathrm{~mL} n$-hexane, dissolved in $2 \mathrm{~mL}$ THF and layered with $5 \mathrm{~mL}$ toluene. The mixture was stored at $8{ }^{\circ} \mathrm{C}$. Compound $2 \mathrm{c}$ was isolated after 1 day as dark green plates. Yield: $110.2 \mathrm{mg}(0.17 \mathrm{mmol}, 86 \%) .{ }^{1} \mathrm{H}$ NMR (THF-d $\left.\mathrm{d}_{8}, 293 \mathrm{~K}\right): \delta[\mathrm{ppm}]=3.78(\mathrm{~s}, 33 \mathrm{H}, 12 \mathrm{c} 4), 1.45\left(\mathrm{~s}, 15 \mathrm{H}, \mathrm{C}_{5}\left(\mathrm{CH}_{3}\right)_{5}\right)$, $0.03\left(\mathrm{~d}, 9 \mathrm{H},{ }^{3} \mathrm{~J}_{\mathrm{P}-\mathrm{H}}=10.8 \mathrm{~Hz},-\mathrm{C}\left(\mathrm{CH}_{3}\right)_{3}\right) .{ }^{31} \mathrm{P}\left\{{ }^{1} \mathrm{H}\right\}$ NMR $\left(\mathrm{THF}-\mathrm{d}_{8}, 293 \mathrm{~K}\right): \delta$ $[\mathrm{ppm}]=105.6\left(\mathrm{~m}, 1 \mathrm{P}, \mathrm{P}_{\mathrm{A}}\right), 19.6\left(\mathrm{~m}, 2 \mathrm{P}, \mathrm{P}_{\mathrm{M}, \mathrm{M}^{\prime}}\right),-70.2\left(\mathrm{~m}, 2 \mathrm{P}, \mathrm{P}_{\mathrm{x}, \mathrm{x}^{\prime}}\right) .{ }^{31} \mathrm{P}$ NMR $\left(\right.$ THF- $\left.\mathrm{d}_{8}, 293 \mathrm{~K}\right): \delta[\mathrm{ppm}]=105.6\left(\mathrm{~m}, 1 \mathrm{P}, \mathrm{P}_{\mathrm{A}}\right), 19.6\left(\mathrm{~m}, 2 \mathrm{P}, \mathrm{P}_{\mathrm{M}, \mathrm{M}^{\prime}}\right),-70.2(\mathrm{~m}, 2 \mathrm{P}$, $\mathrm{P}_{\mathrm{x}, \mathrm{x}^{\prime}}$ ); (for coupling constants, see Supplementary Tables 2, 3). ESI-MS (anion, DME): $m / z=403.00\left(100 \%,[\mathrm{M}]^{-}\right)$; analysis (calcd., found for $\left.\mathrm{C}_{30} \mathrm{H}_{56} \mathrm{FeLiO}_{8} \mathrm{P}_{5}\right)$ : C (47.26, 47.61), H (7.40, 7.49).

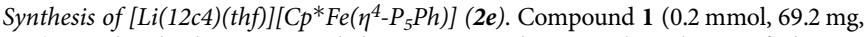
1 eq) was dissolved in THF, cooled to $-80^{\circ} \mathrm{C}$ and a 1.9 molar solution of PhLi in dibutyl ether $(0.2 \mathrm{mmol}, 0.11 \mathrm{~mL}, 1 \mathrm{eq})$ was added. A colour change from green to brown occurred. Two equivalents of 12-crown- $4(0.4 \mathrm{mmol}, 0.12 \mathrm{~mL})$ were added and the solution was stirred overnight and allowed to reach room temperature. The solvent was removed under reduced pressure. The resulting brownish-green residue was washed with $10 \mathrm{~mL}$ of $n$-hexane and again dissolved with $3 \mathrm{~mL}$ of THF layered with $10 \mathrm{~mL}$ of $n$-hexane and stored at room temperature. Dark green blocks of $2 \mathbf{e}$ were isolated after 1 week. Yield: $102.0 \mathrm{mg}(0.15 \mathrm{mmol}, 75 \%) .{ }^{1} \mathrm{H}$ NMR (THF-d $\mathrm{d}_{8}$, $293 \mathrm{~K}): \delta[\mathrm{ppm}]=6.56\left(\mathrm{~m}, 5 \mathrm{H},-\mathrm{C}_{6} \mathrm{H}_{5}\right), 3.72(\mathrm{~s}, 17 \mathrm{H}, 12 \mathrm{c} 4), 3.60\left(\mathrm{~m}, 3 \mathrm{H}, \mathrm{THF}-\mathrm{H}_{8}\right)$, 1.77 (m, 3H, THF- $\left.\mathrm{H}_{8}\right), 1.51\left(\mathrm{~s}, 15 \mathrm{H}, \mathrm{C}_{5}\left(\mathrm{CH}_{3}\right)_{5}\right) .{ }^{31} \mathrm{P}\left\{{ }^{1} \mathrm{H}\right\}$ NMR $\left(\mathrm{C}_{6} \mathrm{D}_{6}, 293 \mathrm{~K}\right): \delta^{-}$ $[\mathrm{ppm}]=79.3\left(\mathrm{~m}, 1 \mathrm{P}, \mathrm{P}_{\mathrm{A}}\right), 21.1\left(\mathrm{~m}, 2 \mathrm{P}, \mathrm{P}_{\mathrm{M}, \mathrm{M}^{\prime}}\right),-61.84\left(\mathrm{~m}, 2 \mathrm{P}, \mathrm{P}_{\mathrm{x}, \mathrm{x}^{\prime}}\right){ }^{31} \mathrm{P}$ NMR $\left(\mathrm{C}_{6} \mathrm{D}_{6}, 293 \mathrm{~K}\right): \delta[\mathrm{ppm}]=79.3\left(\mathrm{~m}, 1 \mathrm{P}, \mathrm{P}_{\mathrm{A}}\right), 21.1\left(\mathrm{~m}, 2 \mathrm{P}, \mathrm{P}_{\mathrm{M}, \mathrm{M}^{\prime}}\right),-61.84\left(\mathrm{~m}, 2 \mathrm{P}, \mathrm{P}_{\mathrm{x}, \mathrm{x}^{\prime}}\right)$; (For coupling constants, see Supplementary Table 4). ESI-MS (anion, DME): no signal can be assigned; analysis (calcd., found for $\mathrm{C}_{28} \mathrm{H}_{44} \mathrm{FeP}_{5} \mathrm{LiO}_{5}$ ): C $(49.58,49.80)$, $\mathrm{H}(6.54,6.53)$.

Synthesis of $\left[C p^{*} F e\left\{\eta^{4}-P_{5}\left(\mathrm{NMe}_{2}\right) \mathrm{Me}\right\}\right]$ (3a). Compound 2a $(0.3 \mathrm{mmol}, 168.0 \mathrm{mg}$, 1 eq) was dissolved in $50 \mathrm{~mL}$ THF. A 1.11 molar solution of $\mathrm{MeI}$ in diethylether $(0.3 \mathrm{mmol}, 0.27 \mathrm{~mL}, 1 \mathrm{eq})$ was added. The mixture was allowed to stir overnight. The solvent was removed under reduced pressure and a brown solution was extracted with $20 \mathrm{~mL} n$-hexane and filtered over diatomaceous earth. The solvent was reduced to $5 \mathrm{~mL}$ and stored at $-30{ }^{\circ} \mathrm{C}$. 3a was formed as dark prisms after 1 day. Yield: $69.1 \mathrm{mg}(0.17 \mathrm{mmol}, 57 \%) .{ }^{1} \mathrm{H}$ NMR $\left(\mathrm{C}_{6} \mathrm{D}_{6}, 293 \mathrm{~K}\right): \delta[\mathrm{ppm}]=1.86$ $\left(\mathrm{dt}, 3 \mathrm{H},{ }^{2} J_{\mathrm{P}-\mathrm{H}}=11.7 \mathrm{~Hz},{ }^{3} J_{\mathrm{P}-\mathrm{H}}=5.8 \mathrm{~Hz},-\left(\mathrm{CH}_{3}\right), 1.53\left(\mathrm{~d},{ }^{3} J_{\mathrm{P}-\mathrm{H}}=10.4 \mathrm{~Hz}, 6 \mathrm{H}\right.\right.$, $\left.\mathrm{N}\left(\mathrm{CH}_{3}\right)_{2}\right) .{ }^{31} \mathrm{P}\left\{{ }^{1} \mathrm{H}\right\} \operatorname{NMR}\left(\mathrm{C}_{6} \mathrm{D}_{6}, 293 \mathrm{~K}\right): \delta[\mathrm{ppm}]=130.8\left(\mathrm{~m}, 1 \mathrm{P}, \mathrm{P}_{\mathrm{A}}\right),-65.1(\mathrm{~m}$, $\left.2 \mathrm{P}, \mathrm{P}_{\mathrm{x}, \mathrm{x}^{\prime}}\right), 37.7\left(\mathrm{~m}, 2 \mathrm{P}, \mathrm{P}_{\mathrm{M}, \mathrm{M}^{\prime}}\right) .{ }^{31} \mathrm{P}$ NMR $\left(\mathrm{C}_{6} \mathrm{D}_{6}, 293 \mathrm{~K}\right): \delta[\mathrm{ppm}]=130.8(\mathrm{~m}, 1 \mathrm{P}$, $\left.\mathrm{P}_{\mathrm{A}}\right),-65.1\left(\mathrm{~m}, 2 \mathrm{P}, \mathrm{P}_{\mathrm{x}, \mathrm{x}^{\prime}}\right), 37.7\left(\mathrm{~m}, 2 \mathrm{P}, \mathrm{P}_{\mathrm{M}, \mathrm{M}^{\prime}}\right)$ (for coupling constants, see Supplementary Table 4). LIFDI-MS (toluene): $405.02\left(100 \%\right.$, [M] $\left.{ }^{+}\right)$; analysis (calcd., found for $\left.\mathrm{C}_{13} \mathrm{H}_{24} \mathrm{FeP}_{5} \mathrm{~N}\right)$ : $\mathrm{C}(38.55,38.14), \mathrm{H}(5.97,6.03)$.

Synthesis of $\left[\mathrm{Cp}^{*} \mathrm{Fe}\left\{\eta^{4}-\mathrm{P}_{5}\left(\mathrm{CH}_{2} \mathrm{SiMe}_{3}\right) \mathrm{Me}\right\}\right]$ (3b). Compound 2b $(1.33 \mathrm{mmol}$, $686.0 \mathrm{mg}, 1 \mathrm{eq}$ ) was dissolved in $100 \mathrm{~mL}$ THF. $1.2 \mathrm{~mL}$ of a 1.110 molar solution of $\mathrm{MeI}$ in $\mathrm{Et}_{2} \mathrm{O}$ (1.33 mmol, $\left.1 \mathrm{eq}\right)$ was added under strong stirring at room temperature and the solution was stirred overnight. The formation of a white precipitate was observed on the glass wall. The solvent was removed, $\mathbf{3 b}$ extracted with
$40 \mathrm{~mL}$ of $n$-hexane and filtered over diatomaceous earth. The solvent was reduced to $10 \mathrm{~mL}$. Complex $\mathbf{3 b}$ was isolated as black plates. Crystals for X-ray structure analysis were obtained from a concentrated $n$-hexane solution at $-30^{\circ} \mathrm{C}$. Yield: $426 \mathrm{mg}(0.94 \mathrm{mmol}, 71 \%) .{ }^{1} \mathrm{H}$ NMR $\left(\mathrm{C}_{6} \mathrm{D}_{6}, 293 \mathrm{~K}\right): \delta[\mathrm{ppm}]=1.80(\mathrm{dt}, 3 \mathrm{H}$, $\left.{ }^{2} J_{\mathrm{P}-\mathrm{H}}=11.9 \mathrm{~Hz},{ }^{3} \mathrm{~J}_{\mathrm{P}-\mathrm{H}}=5.8 \mathrm{~Hz},-\mathrm{CH}_{3}\right), 1.67\left(\mathrm{~s}, 15 \mathrm{H}, \mathrm{C}_{5}\left(\mathrm{CH}_{3}\right)_{5}\right), 0.25(\mathrm{~d}, 2 \mathrm{H}$, $\left.{ }^{2} J_{\mathrm{P}-\mathrm{H}}=14.9 \mathrm{~Hz}, \mathrm{CH}_{2} \mathrm{Si}\left(\mathrm{CH}_{3}\right)_{3}\right),-0.18\left(\mathrm{~s}, 9 \mathrm{H}, \mathrm{CH}_{2} \mathrm{Si}\left(\mathrm{CH}_{3}\right)_{3}\right) .{ }^{3} \mathrm{P}\left\{{ }^{1} \mathrm{H}\right\} \mathrm{NMR}\left(\mathrm{C}_{6} \mathrm{D}_{6}\right.$, $293 \mathrm{~K}): \delta[\mathrm{ppm}]=129.4\left(\mathrm{~m}, 1 \mathrm{P}, \mathrm{P}_{\mathrm{A}}\right), 37.0\left(\mathrm{~m}, 2 \mathrm{P}, \mathrm{P}_{\mathrm{M}, \mathrm{M}^{\prime}}\right),-96.7\left(\mathrm{~m}, 2 \mathrm{P}, \mathrm{P}_{\mathrm{x}, \mathrm{x}^{\prime}}\right) .{ }^{31} \mathrm{P}$ $\operatorname{NMR}\left(\mathrm{C}_{6} \mathrm{D}_{6}, 293 \mathrm{~K}\right): \delta[\mathrm{ppm}]=129.4\left(\mathrm{~m}, 1 \mathrm{P}, \mathrm{P}_{\mathrm{A}}\right), 37.0\left(\mathrm{~m}, 2 \mathrm{P}, \mathrm{P}_{\mathrm{M}, \mathrm{M}^{\prime}}\right),-96.7(\mathrm{~m}$, $2 \mathrm{P}, \mathrm{P}_{\mathrm{x}, \mathrm{x}^{\prime}}$ ); (for coupling constants, see Supplementary Table 5). LIFDI-MS (toluene): $448.03\left(100 \%,[\mathrm{M}]^{+}\right)$; analysis (calcd., found for $\left.\mathrm{C}_{15} \mathrm{H}_{29} \mathrm{FeP}_{5} \mathrm{Si}\right)$ : C (40.20, 39.64), H $(6.52,6.48)$.

Synthesis of $\left[\mathrm{Cp}^{*} \mathrm{Fe}\left(\eta^{4}-\mathrm{P}_{5} \mathrm{Me} \mathrm{e}_{2}\right)\right](3 \mathrm{c})$. Method A: Compound $2 \mathrm{c}(3.53 \mathrm{mmol}, 2.26 \mathrm{~g}$, 1 eq) was dissolved in DME and $3.18 \mathrm{~mL}$ of a 1.11 molar solution of MeI $(3.53 \mathrm{mmol}, 1 \mathrm{eq})$ in $\mathrm{Et}_{2} \mathrm{O}$ was added at room temperature and stirred overnight. The solvent was removed in vacuo, a brown residue was extracted with $n$-hexane and filtered over silica gel. The solvent was removed under reduced pressure, dissolved in $5 \mathrm{~mL}$ of $\mathrm{CH}_{2} \mathrm{Cl}_{2}$, layered with $20 \mathrm{~mL}$ of acetonitrile and stored at $-30^{\circ} \mathrm{C}$. Dark green blocks of $3 \mathrm{c}$ were isolated after 1 week. Yield: $938 \mathrm{mg}$ (2.49 mmol, $71 \%)$.

Method B: $\left[\mathrm{K}(\mathrm{dme})_{2}\right]_{2}\left[\mathrm{Cp} * \mathrm{Fe}\left(\eta^{4}-\mathrm{P}_{5}\right)\right]\left(\mathbf{1}^{\prime}\right)(0.2 \mathrm{mmol}, 165.9 \mathrm{mg}, 1 \mathrm{eq})$ was dissolved in $10 \mathrm{~mL}$ THF and $0.36 \mathrm{~mL}$ of a 1.11 molar solution of MeI $(0.4 \mathrm{mmol}$, 2 eq) in $\mathrm{Et}_{2} \mathrm{O}$ was added at room temperature. The reaction mixture was stirred for five min and the solvent was partly reduced in vacuo. The performed ${ }^{31} \mathrm{P}\left\{{ }^{1} \mathrm{H}\right\} \mathrm{NMR}$ experiment (Supplementary Fig. 69) of the reaction in THF/ $\mathrm{C}_{6} \mathrm{D}_{6}$-capillary matches the spectroscopic data of method $\mathrm{A}$ and shows a quantitative formation of 3c. ${ }^{1} \mathrm{H}$ NMR $\left(\mathrm{C}_{6} \mathrm{D}_{6}, 293 \mathrm{~K}\right): \delta[\mathrm{ppm}]=1.61\left(\mathrm{~s}, 15 \mathrm{H}, \mathrm{C}_{5}\left(\mathrm{CH}_{3}\right)_{5}\right), 1.51(\mathrm{dt}, 3 \mathrm{H}$, $\left.{ }^{2} J_{\mathrm{P}-\mathrm{H}}=11.1 \mathrm{~Hz},{ }^{3} J_{\mathrm{P}-\mathrm{H}}=5.5 \mathrm{~Hz},-\mathrm{CH}_{3}(\mathrm{exo})\right), 0.06\left(\mathrm{~d}, 3 \mathrm{H},{ }^{2} \mathrm{~J}_{\mathrm{P}-\mathrm{H}}=11.5 \mathrm{~Hz}\right.$, $\left.-\mathrm{CH}_{3}(\mathrm{endo})\right) .{ }^{31} \mathrm{P}\left\{{ }^{1} \mathrm{H}\right\} \operatorname{NMR}\left(\mathrm{C}_{6} \mathrm{D}_{6}, 293 \mathrm{~K}\right): \delta[\mathrm{ppm}]=117.2\left(\mathrm{~m}, 1 \mathrm{P}, \mathrm{P}_{\mathrm{A}}\right), 35.4(\mathrm{~m}$, $\left.2 \mathrm{P}, \mathrm{P}_{\mathrm{M}, \mathrm{M}^{\prime}}\right),-122.7\left(\mathrm{~m}, 2 \mathrm{P}, \mathrm{P}_{\mathrm{x}, \mathrm{x}^{\prime}}\right) .{ }^{31} \mathrm{P}$ NMR $\left(\mathrm{C}_{6} \mathrm{D}_{6}, 293 \mathrm{~K}\right): \delta[\mathrm{ppm}]=117.2(\mathrm{~m}, 1 \mathrm{P}$ $\left.\mathrm{P}_{\mathrm{A}}\right), 35.4\left(\mathrm{~m}, 2 \mathrm{P}, \mathrm{P}_{\mathrm{M}, \mathrm{M}^{\prime}}\right),-122.7\left(\mathrm{~m}, 2 \mathrm{P}, \mathrm{P}_{\mathrm{x}, \mathrm{x}^{\prime}}\right)$ ) (for coupling constants, see Supplementary Table 6). LIFDI-MS (toluene): $376.97\left(100 \%,[\mathrm{M}]^{+}\right), 360.95(40 \%$, $\left.[\mathrm{M}]^{+}-\mathrm{CH}_{3}\right), 345.92\left(20 \%,[\mathrm{M}]^{+}-\left(\mathrm{CH}_{3}\right)_{2}\right), 314.95\left(10 \%[\mathrm{M}]^{+}-\mathrm{P}\left(\mathrm{CH}_{3}\right)_{2}\right)$; analysis (calcd., found for $\left.\mathrm{C}_{12} \mathrm{H}_{21} \mathrm{FeP}_{5}\right)$ : $\mathrm{C}(38.33,38.37), \mathrm{H}(5.63,5.63)$.

Synthesis of $\left[C p^{*} F e\left(\eta^{4}-P_{5} M e^{i} P r\right)\right](3 d)$. To a solution of $2 \mathrm{c}(0.15 \mathrm{mmol}, 90 \mathrm{mg}, 1 \mathrm{eq})$ in $10 \mathrm{~mL}$ DME. $0.03 \mathrm{~mL}$ of isopropyl iodide $(0.15 \mathrm{mmol}, 1 \mathrm{eq})$ was added. The brownish solution was stirred overnight, all volatiles were removed in vacuum and the brown residue was dissolved in $n$-hexane and filtered through a frit. The resulting solution was concentrated to $3 \mathrm{~mL}$ and stored at $-30^{\circ} \mathrm{C}$. Dark red blocks of [Cp* $\left.\mathrm{Fe}\left(\eta^{4}-\mathrm{P}_{5}{ }^{i} \mathrm{PrMe}\right)\right]$ (3d) could be isolated after 2 days. Yield: $43 \mathrm{mg}$, $(0.106 \mathrm{mmol}, 72 \%$ yield $) .{ }^{1} \mathrm{H}$ NMR $\left(\mathrm{C}_{6} \mathrm{D}_{6}, 293 \mathrm{~K}\right): \delta[\mathrm{ppm}]=2.40(\mathrm{~m}, 1 \mathrm{H}$, $\left.-\mathrm{CH}\left(\mathrm{CH}_{3}\right)_{2}\right), 1.59\left(\mathrm{~s}, 15 \mathrm{H}, \mathrm{C}_{5}\left(\mathrm{CH}_{3}\right)_{5}\right), 1.01\left(\mathrm{dd}, 6 \mathrm{H},-\mathrm{CH}\left(\mathrm{CH}_{3}\right)_{2},{ }^{3} J_{\mathrm{H}-\mathrm{H}}=7.1 \mathrm{~Hz}\right.$, $\left.{ }_{3}^{3} \overline{\mathrm{P}-\mathrm{H}}=15.0 \mathrm{~Hz}\right), 0.05\left(\mathrm{~d}, 3 \mathrm{H},-\mathrm{CH}_{3}, J_{\mathrm{P}-\mathrm{H}}=10.5 \mathrm{~Hz}\right) .{ }^{31} \mathrm{P}\left\{{ }^{1} \mathrm{H}\right\}$ NMR $\left(\mathrm{C}_{6} \mathrm{D}_{6}, 293 \mathrm{~K}\right):$ $\delta[\mathrm{ppm}]=151.8\left(\mathrm{~m}, 1 \mathrm{P}, \mathrm{P}_{\mathrm{A}}\right), 33.3^{2}\left(\mathrm{~m}, 2 \mathrm{P}, \mathrm{P}_{\mathrm{M}, \mathrm{M}^{\prime}}\right),-135.8\left(\mathrm{~m}, 2 \mathrm{P}, \mathrm{P}_{\mathrm{x}, \mathrm{x}^{\prime}}\right) .{ }^{31} \mathrm{P} \mathrm{NMR}$ $\left(\mathrm{C}_{6} \mathrm{D}_{6}, 293 \mathrm{~K}\right): \delta[\mathrm{ppm}]=151.8\left(\mathrm{~m}, 1 \mathrm{P}, \mathrm{P}_{\mathrm{A}}\right), 33.3\left(\mathrm{~m}, 2 \mathrm{P}, \mathrm{P}_{\mathrm{M}, \mathrm{M}^{\prime}}\right),-135.8(\mathrm{~m}, 2 \mathrm{P}$, $\mathrm{P}_{\mathrm{x}, \mathrm{x}^{\prime}}$ ); (for coupling constants see Supplementary Table 7). FD-MS (toluene): 404.00 $\left(100 \%,[\mathrm{M}]^{+}\right)$; analysis (calcd., found for $\left.\mathrm{C}_{14} \mathrm{H}_{25} \mathrm{FeP}_{5}\right)$ : $\mathrm{C}(41.61,41.60), \mathrm{H}$ $(6.24,6.11)$.

Synthesis of [C $\left.p^{*} \mathrm{Fe}\left(\eta^{4}-\mathrm{P}_{5}{ }^{\mathrm{t}} \mathrm{BuMe}\right)\right]$ (3e). Method A: A solution of $\mathbf{2 d}(0.2 \mathrm{mmol}$, $152.5 \mathrm{mg}, 1 \mathrm{eq}$ ) in $10 \mathrm{~mL}$ THF was cooled to $-80^{\circ} \mathrm{C}$ and a 1.005 molar solution of MeI in DME $(0.2 \mathrm{mmol}, 0.20 \mathrm{~mL}, 1 \mathrm{eq})$ was added. A colour change from green to brown occurred and a colourless solid was formed. The mixture was allowed to stir overnight and reach room temperature. The solvent was removed under reduced pressure and a brown solution was extracted with $10 \mathrm{~mL}$ toluene and filtered over diatomaceous earth. The solvent was removed in vacuo. The brown residue was dissolved in $2 \mathrm{~mL}$ THF, layered with $4 \mathrm{~mL} n$-hexane and stored at $-30^{\circ} \mathrm{C}$. $\left[\mathrm{Cp} * \mathrm{Fe}\left(\eta^{4}-\mathrm{P}_{5}{ }^{t} \mathrm{BuMe}\right)\right] 3 \mathrm{e}$ was formed as dark green blocks after 1 day. Yield: $71.1 \mathrm{mg}(0.17 \mathrm{mmol}, 85 \%)$.

Method B: $\left[\mathrm{K}(\mathrm{dme})_{2}\right]_{2}\left[\mathrm{Cp} * \mathrm{Fe}\left(\eta^{4}-\mathrm{P}_{5}\right)\right]\left(\mathbf{1}^{\prime}\right)(0.4 \mathrm{mmol}, 313.8 \mathrm{mg}, 1 \mathrm{eq})$ was dissolved in $10 \mathrm{~mL}$ THF, cooled to $-80^{\circ} \mathrm{C}$ and $0.05 \mathrm{~mL}{ }^{t} \mathrm{BuI}(0.4 \mathrm{mmol}, 1 \mathrm{eq})$ was added. The reaction mixture was stirred for $10 \mathrm{~min}$ and $0.18 \mathrm{~mL}$ of a 1.11 molar solution of $\mathrm{MeI}(0.2 \mathrm{mmol}, 1 \mathrm{eq})$ in $\mathrm{Et}_{2} \mathrm{O}$ was added. The resulting brown solution was stirred overnight and the solvent was partly reduced in vacuo. The performed ${ }^{31} \mathrm{P}\left\{{ }^{1} \mathrm{H}\right\}$ NMR experiment (Supplementary Fig. 70 ) of the reaction in THF/ $\mathrm{C}_{6} \mathrm{D}_{6}$ capillary matches the spectroscopic data of method $\mathrm{A}$ and shows a quantitative formation of 3e. ${ }^{1} \mathrm{H}$ NMR $\left(\mathrm{C}_{6} \mathrm{D}_{6}, 293 \mathrm{~K}\right): \delta[\mathrm{ppm}]=1.74\left(\mathrm{~m}, 3 \mathrm{H},-\mathrm{CH}_{3}\right), 1.62(\mathrm{~s}$, $\left.15 \mathrm{H}, \mathrm{C}_{5}\left(\mathrm{CH}_{3}\right)_{5}\right), 0.26\left(\mathrm{~d}, 9 \mathrm{H},{ }^{3} J_{\mathrm{P}-\mathrm{H}}=14.5 \mathrm{~Hz},-\mathrm{C}\left(\mathrm{CH}_{3}\right)_{3}\right),{ }^{31} \mathrm{P}\left\{{ }^{1} \mathrm{H}\right\} \mathrm{NM} \overline{\mathrm{R}}\left(\mathrm{C}_{6} \mathrm{D}_{6}\right.$, $293 \mathrm{~K}): \delta[\mathrm{ppm}]=151.9\left(\mathrm{~m}, 1 \mathrm{P}, \mathrm{P}_{\mathrm{A}}\right), 47.0\left(\mathrm{~m}, 2 \mathrm{P}, \mathrm{P}_{\mathrm{M}, \mathrm{M}^{\prime}}\right),-117.2\left(\mathrm{~m}, 2 \mathrm{P}, \mathrm{P}_{\mathrm{x}, \mathrm{x}^{\prime}}\right) .{ }^{31} \mathrm{P}$ $\operatorname{NMR}\left(\mathrm{C}_{6} \mathrm{D}_{6}, 293 \mathrm{~K}\right): \delta[\mathrm{ppm}]=151.9\left(\mathrm{~m}, 1 \mathrm{P}, \mathrm{P}_{\mathrm{A}}\right), 47.0\left(\mathrm{~m}, 2 \mathrm{P}, \mathrm{P}_{\mathrm{M}, \mathrm{M}^{\prime}}\right),-117.2(\mathrm{~m}$, 2P, $\mathrm{P}_{\mathrm{x}, \mathrm{x}^{\prime}}$ ): (for coupling constants, see Supplementary Table 8). LIFDI-MS (toluene): $418.02\left(100 \%,[\mathrm{M}]^{+}\right)$; analysis (calcd., found for $\mathrm{C}_{15} \mathrm{H}_{27} \mathrm{FeP}_{5}$ ): C (43.09, 43.63), H $(6.51,6.36)$.

Synthesis of $\left[C p^{*} \mathrm{Fe}\left(\eta^{4}-P_{5} P h M e\right)\right]$ (3f). Compound $1(0.4 \mathrm{mmol}, 138.4 \mathrm{mg}, 1 \mathrm{eq})$ was dissolved in $20 \mathrm{~mL}$ of DME, cooled to $-50^{\circ} \mathrm{C}$ and $0.22 \mathrm{~mL}$ of a 1.9 molar solution of $\mathrm{PhLi}(0.4 \mathrm{mmol}, 1 \mathrm{eq})$ in dibutyl ether was added. The solution was stirred for $2 \mathrm{~h}$ and allowed to reach room temperature. To the brown solution, a 1.11 molar 
solution of $\mathrm{MeI}(0.4 \mathrm{mmol}, 0.36 \mathrm{~mL}, 1 \mathrm{eq})$ in $\mathrm{Et}_{2} \mathrm{O}$ was added. The solution was stirred for $18 \mathrm{~h}$, the solvent removed under reduced pressure, the remaining brown residue extracted with $3 \times 5 \mathrm{~mL}$ of $n$-hexane and filtered over diatomaceous earth The volume was reduced in vacuo and the solution stored at $-30^{\circ} \mathrm{C}$. Compound $\mathbf{3 f}$ was isolated after 3 days as dark green plates. Yield: $132.0 \mathrm{mg}(0.30 \mathrm{mmol}, 75 \%) .{ }^{1} \mathrm{H}$ $\operatorname{NMR}\left(\mathrm{C}_{6} \mathrm{D}_{6}, 293 \mathrm{~K}\right): \delta[\mathrm{ppm}]=6.82\left(\mathrm{~m}, 2 \mathrm{H},-\mathrm{C}_{6} \mathrm{H}_{5}\right),=6.71\left(\mathrm{~m}, 3 \mathrm{H},-\mathrm{C}_{6} \mathrm{H}_{5}\right), 1.95$ $\left(\mathrm{dt}, 3 \mathrm{H},{ }^{2} J_{\mathrm{P}-\mathrm{H}}=10.8 \mathrm{~Hz},{ }^{3} J_{\mathrm{P}-\mathrm{H}}=5.4 \mathrm{~Hz},-\mathrm{CH}_{3}\right), 1.64^{-}\left(\mathrm{s}, 15 \mathrm{H}, \mathrm{C}_{5}\left(\mathrm{CH}_{3}\right)_{5}\right) .{ }^{31} \overline{\mathrm{P}}\left\{{ }^{1} \mathrm{H}\right\}$ $\operatorname{NMR}\left(\mathrm{C}_{6} \mathrm{D}_{6}, 293 \mathrm{~K}\right): \delta[\mathrm{ppm}]=117.7\left(\mathrm{~m}, 1 \mathrm{P}^{-}, \mathrm{P}_{\mathrm{A}}\right), 40.5\left(\mathrm{~m}, 2 \mathrm{P}, \mathrm{P}_{\mathrm{M}_{1} \mathrm{M}^{\prime}}\right),-109.5(\mathrm{~m}$, $\left.2 \mathrm{P}, \mathrm{P}_{\mathrm{x}, \mathrm{x}^{\prime}}\right) .{ }^{31} \mathrm{P}$ NMR $\left(\mathrm{C}_{6} \mathrm{D}_{6}, 293 \mathrm{~K}\right): \delta[\mathrm{ppm}]=117.7\left(\mathrm{~m}, 1 \mathrm{P}, \mathrm{P}_{\mathrm{A}}\right), 40.5\left(\mathrm{~m}, 2 \mathrm{P}, \mathrm{P}_{\mathrm{M}, \mathrm{M}^{\prime}}\right)$, $-109.5\left(\mathrm{~m}, 2 \mathrm{P}, \mathrm{P}_{\mathrm{x}_{\mathrm{x}}{ }^{\prime}}\right.$ ); (for coupling constants, see Supplementary Table 9). LIFDIMS (toluene): $437.96\left(100 \%,[\mathrm{M}]^{+}\right)$; analysis (calcd., found for $\mathrm{C}_{17} \mathrm{H}_{23} \mathrm{FeP}_{5}$ ): $\mathrm{C}$ (46.61, 47.09), H (5.29, 5.26).

Synthesis of $P R^{\prime} R^{\prime \prime} R^{\prime \prime \prime}(4 a-c)$. Compound 3d (0.1 mmol, $\left.40.4 \mathrm{mg}, 1 \mathrm{eq}\right), 3 \mathrm{e}(0.2 \mathrm{mmol}$, $83.6 \mathrm{mg}, 1 \mathrm{eq})$ or $3 \mathrm{f}(0.1 \mathrm{mmol}, 43.8 \mathrm{mg}, 1 \mathrm{eq})$ were dissolved in DME and cooled to $-50^{\circ} \mathrm{C}$. To the brownish-green solution, a $-50^{\circ} \mathrm{C}$ cold solution of $\mathrm{KBnz}^{50}(0.1 \mathrm{mmol}$, $13.0 \mathrm{mg}$, lequ. for $\mathbf{3 d}, \mathbf{3 f}, 0.2 \mathrm{mmol}, 26.0 \mathrm{mg}$, lequ. for $\mathbf{3 e}$ ) in DME was added. The colour changed to dark red and rapidly back to brownish-green. The solution was stirred overnight and allowed to reach room temperature. The solvent was slowly removed under reduced pressure (note: in order to avoid the loss of the desired phosphine by removal of the solvent, lower boiling solvents like THF can be used for the reaction). The oily residue was extracted with $n$-pentane $(3 \times 5 \mathrm{~mL})$ and decanted off from the remaining solid (compound 5, see below). The solvent was removed in vacuo and compound $4 \mathrm{a}-\mathrm{c}\left(\mathbf{a}: \mathrm{R}^{\prime}=\mathrm{Me}, \mathrm{R}^{\prime \prime}={ }^{i} \mathrm{Pr}, \mathrm{R}^{\prime \prime \prime}=\mathrm{Bnz} ; \mathbf{b}: \mathrm{R}^{\prime}={ }^{t} \mathrm{Bu}, \mathrm{R}^{\prime \prime}=\mathrm{Me}, \mathrm{R}\right.$ "' $\left.=\mathrm{Bnz} ; \mathrm{c}: \mathrm{R}^{\prime}=\mathrm{Ph}, \mathrm{R}^{\prime \prime}=\mathrm{Me}, \mathrm{R}^{\prime \prime \prime}=\mathrm{Bnz}\right)$ can be isolated as a viscous liquid. Yield: 4a: $14.8 \mathrm{mg}$ (0.082 mmol, 82\%), 4b: $21.5 \mathrm{mg}(0.11 \mathrm{mmol}, 55 \%), 4 \mathrm{c}: 17.1 \mathrm{mg}$ (0.08 mmol, 80\%).

${ }^{1} \mathrm{H}$ NMR: 4a $\left(\mathrm{C}_{6} \mathrm{D}_{6}, 293 \mathrm{~K}\right): \delta[\mathrm{ppm}]=7.07\left(\mathrm{~m}, 5 \mathrm{H},-\mathrm{CH}_{2}-\mathrm{C}_{6} \mathrm{H}_{\underline{5}}\right), 2.75(\mathrm{dd}, 1 \mathrm{H}$, $\left.{ }^{3} J_{\mathrm{P}-\mathrm{H}}=13.14 \mathrm{~Hz},{ }^{3} J_{\mathrm{H}-\mathrm{H}}=3.51 \mathrm{~Hz},-\mathrm{CH}_{\underline{2}}-\mathrm{Ph}\right), 2.41\left(\mathrm{dd}, 1 \mathrm{H},{ }^{3} J_{\mathrm{P}-\mathrm{H}}=13.18 \mathrm{~Hz}\right.$, $\left.{ }^{3} J_{\mathrm{H}-\mathrm{H}}=1.69 \mathrm{~Hz},-\mathrm{CH}_{2}-\mathrm{Ph}\right), 1.28\left(\mathrm{~m}, 1 \overline{\mathrm{H}},-(\mathrm{CH})-\mathrm{CH}_{3}\right), 0.99(\mathrm{dd}, 3 \mathrm{H}$, ${ }^{3} J_{\mathrm{P}-\mathrm{H}}=14.1 \mathrm{~Hz},{ }^{2} J_{\mathrm{H}-\mathrm{H}}=7.0 \mathrm{~Hz},-(\mathrm{CH})-\left(\mathrm{CH}_{\underline{3}}\right)_{2}, 0.91\left(\mathrm{dd}, 3 \mathrm{H},{ }^{3} J_{\mathrm{P}-\mathrm{H}}=12.2 \mathrm{~Hz}\right.$, $\left.{ }^{2} J_{\mathrm{H}-\mathrm{H}}=6.9 \mathrm{~Hz},-(\mathrm{CH})-\left(\mathrm{CH}_{3}\right)_{2}\right), 0.73\left(\mathrm{~d}, 9 \mathrm{H}^{-}{ }^{2} J_{\mathrm{P}-\mathrm{H}}=3.5 \mathrm{~Hz},-\mathrm{CH}_{3}\right) ; \mathbf{4 b}\left(\mathrm{C}_{6} \mathrm{D}_{6}\right.$, $293 \mathrm{~K}): \delta[\mathrm{ppm}]=7.13\left(\mathrm{~m}, 8 \mathrm{H},-\mathrm{CH}_{2}-\mathrm{C}_{6} \mathrm{H}_{5}\right), 2.76\left(\mathrm{dd}, 1 \mathrm{H},{ }^{3} \mathrm{~J}_{\mathrm{P}-\mathrm{H}}=12.2 \mathrm{~Hz}\right.$, $\left.{ }^{3} J_{\mathrm{H}-\mathrm{H}}=3.9 \mathrm{~Hz},-\mathrm{CH}_{2}-\mathrm{Ph}\right), 2.33\left(\mathrm{~d}, 1 \mathrm{H},{ }^{3} J_{\mathrm{P}-\mathrm{H}}=13.0 \mathrm{~Hz},{ }^{3} J_{\mathrm{H}-\mathrm{H}}=4.1 \mathrm{~Hz},-\mathrm{CH}_{2}-\mathrm{Ph}\right)$, $0.94\left(\mathrm{~d}, 9 \mathrm{H},{ }^{3} J_{\mathrm{P}-\mathrm{H}}=11.2 \mathrm{~Hz},-\mathrm{C}\left(\mathrm{CH}_{3}\right)_{3}\right), 0.71\left(\mathrm{~d}, 3 \mathrm{H},{ }^{2} J_{\mathrm{P}-\mathrm{H}}=3.5 \mathrm{~Hz},-\mathrm{CH}_{3}\right) ; 4 \mathrm{c}$ $\left(\mathrm{C}_{6} \mathrm{D}_{6}, 293 \mathrm{~K}\right): \delta[\mathrm{ppm}]=7.21\left(\mathrm{~m}, 5 \mathrm{H},-\mathrm{CH}_{2}-\mathrm{C}_{6} \mathrm{H}_{5}\right), 7.21\left(\mathrm{~m}, 5 \mathrm{H},-\mathrm{CH}_{2}-\overline{\mathrm{C}}_{6} \mathrm{H}_{5}\right)$, $2.95\left(\mathrm{dd}, 2 \mathrm{H},{ }^{2} J_{\mathrm{P}-\mathrm{H}}=13.2 \mathrm{~Hz},{ }^{3} J_{\mathrm{H}-\mathrm{H}}=2.9 \mathrm{~Hz},-\mathrm{CH}_{2}-\mathrm{Ph}\right), 2.79(\mathrm{~d}, 1 \mathrm{H}$,

$\left.{ }^{3} J_{\mathrm{P}-\mathrm{H}}=13.0 \mathrm{~Hz},-\mathrm{CH}_{2}-\mathrm{Ph}\right), 1.10\left(\mathrm{~d}, 3 \mathrm{H},{ }^{2} J_{\mathrm{P}-\mathrm{H}}=4.0 \mathrm{~Hz},-\mathrm{CH}_{3}\right)$.

${ }^{31} \mathrm{P}\left\{{ }^{1} \mathrm{H}\right\}$ NMR: $4 \mathbf{a}\left(\mathrm{C}_{6} \mathrm{D}_{6}, 293 \mathrm{~K}\right): \delta[\mathrm{ppm}]=-18.5(\mathrm{~s}) ; \mathbf{4} \mathbf{b}\left(\mathrm{C}_{6} \mathrm{D}_{6}, 293 \mathrm{~K}\right): \delta$ $[\mathrm{ppm}]=-7.00(\mathrm{~s}) ; 4 \mathrm{c}\left(\mathrm{C}_{6} \mathrm{D}_{6}, 293 \mathrm{~K}\right): \delta[\mathrm{ppm}]=-29.6(\mathrm{~s})$.

${ }^{31}$ P NMR: 4a $\left(\mathrm{C}_{6} \mathrm{D}_{6}, 293 \mathrm{~K}\right): \delta[\mathrm{ppm}]=-18.5(\mathrm{~s}) ; \mathbf{4 b}\left(\mathrm{C}_{6} \mathrm{D}_{6}, 293 \mathrm{~K}\right): \delta$ $[\mathrm{ppm}]=-7.00(\mathrm{~s}, \mathrm{br}) ; 4 \mathrm{c}\left(\mathrm{C}_{6} \mathrm{D}_{6}, 293 \mathrm{~K}\right): \delta[\mathrm{ppm}]=-29.6(\mathrm{~s}, \mathrm{br})$.

${ }^{13} \mathrm{C}\left\{{ }^{1} \mathrm{H}\right\}$ NMR: 4a $\left(\mathrm{C}_{6} \mathrm{D}_{6}, 293 \mathrm{~K}\right): \delta[\mathrm{ppm}]=138.5\left(\mathrm{~d},{ }^{2} J_{\mathrm{P}-\mathrm{C}}=4.1 \mathrm{~Hz}, \mathrm{Ph}\right), 129.1$ $\left(\mathrm{d},{ }^{3} J_{\mathrm{P}-\mathrm{C}}=5.4 \mathrm{~Hz}, \mathrm{Ph}\right), 128.2(\mathrm{~s}, \mathrm{Ph}), 125.5\left(\mathrm{~d},{ }^{4} J_{\mathrm{P}-\mathrm{C}}=2.1 \mathrm{~Hz}, \mathrm{Ph}\right), 34.8(\mathrm{~d}$,

$\left.{ }^{1} J_{\mathrm{P}-\mathrm{C}}=18.64 \mathrm{~Hz},-\left(\mathrm{CH}_{2}\right)-\mathrm{Ph}\right), 26.6\left(\mathrm{~d},{ }^{2} J_{\mathrm{P}-\mathrm{C}}=11.71 \mathrm{~Hz},-(\mathrm{CH})-\left(\mathrm{CH}_{3}\right)_{2}\right), 19.2(\mathrm{~d}$, $\left.{ }^{1} J_{\mathrm{P}-\mathrm{C}}=17.1 \mathrm{~Hz},-(\overline{\mathrm{CH}})-\left(\mathrm{CH}_{3}\right)_{2}\right), 18.3\left(\mathrm{~d},{ }^{2} J_{\mathrm{P}-\mathrm{C}}=12.8 \mathrm{~Hz},-(\mathrm{CH})-\left(\mathrm{CH}_{3}\right)_{2}\right), 8.1(\mathrm{~d}$, $\left.{ }^{1} J_{\mathrm{P}-\mathrm{C}}=20.2 \mathrm{~Hz},-\overline{\mathrm{CH}}_{3}\right) ; 4 \mathbf{b}\left(\mathrm{C}_{6} \mathrm{D}_{6}, 293 \mathrm{~K}\right): \delta[\mathrm{ppm}]=139.1\left(\mathrm{~d},{ }^{2} J_{\mathrm{P}-\mathrm{C}}=6.9 \mathrm{~Hz}, \mathrm{Ph}\right)$, $129.3\left(\mathrm{~d},{ }^{3} J_{\mathrm{P}-\mathrm{C}}=6.3 \mathrm{~Hz}, \mathrm{Ph}\right), 128.3\left(\mathrm{~d},{ }^{5} J_{\mathrm{P}-\mathrm{C}}=0.7 \mathrm{~Hz}, \mathrm{Ph}\right), 125.5\left(\mathrm{~d},{ }^{4} J_{\mathrm{P}-\mathrm{C}}=2.3 \mathrm{~Hz}\right.$, $\mathrm{Ph}), 33.0\left(\mathrm{~d},{ }^{1} J_{\mathrm{P}-\mathrm{C}}=20.8 \mathrm{~Hz},-\left(\mathrm{CH}_{2}\right)-\mathrm{Ph}\right), 27.0\left(\mathrm{~d},{ }^{1} J_{\mathrm{P}-\mathrm{C}}=13.6 \mathrm{~Hz},-\mathrm{C}\left(\mathrm{CH}_{3}\right)_{3}\right), 26.5$ $\left(\mathrm{d},{ }^{2} J_{\mathrm{P}-\mathrm{C}}=13.6 \mathrm{~Hz},-\mathrm{C}\left(\mathrm{CH}_{3}\right)_{3}\right), \overline{6} .2\left(\mathrm{~d},{ }^{1} J_{\mathrm{P}-\mathrm{C}}=23.0 \mathrm{~Hz},-\mathrm{CH}_{3}\right) ; 4 \mathrm{c}\left(\overline{\mathrm{C}}_{6} \mathrm{D}_{6}, 293 \mathrm{~K}\right): \delta$ $[\mathrm{ppm}]=140.1\left(\mathrm{~d},{ }^{1} J_{\mathrm{P}-\mathrm{C}}=17.9 \mathrm{~Hz}, \mathrm{Ph}\right), 137.7\left(\mathrm{~d},{ }^{2} J_{\mathrm{P}-\mathrm{C}}=4.5 \mathrm{~Hz}, \mathrm{Ph}\right), 131.6(\mathrm{~d}$, $\left.{ }^{1} J_{\mathrm{P}-\mathrm{C}}=18.6 \mathrm{~Hz}, \mathrm{Ph}\right), 129.1\left(\mathrm{~d},{ }^{3} J_{\mathrm{P}-\mathrm{C}}=5.4 \mathrm{~Hz}, \mathrm{Ph}\right), 128.2\left(\mathrm{~d},{ }^{2} J_{\mathrm{P}-\mathrm{C}}=11.2 \mathrm{~Hz}, \mathrm{Ph}\right)$, $128.1(\mathrm{~s}, \mathrm{Ph}), 128.1(\mathrm{~s}, \mathrm{Ph}), 125.7\left(\mathrm{~d},{ }^{3} J_{\mathrm{P}-\mathrm{C}}=5.4 \mathrm{~Hz}, \mathrm{Ph}\right), 38.3\left(\mathrm{~d},{ }^{1} J_{\mathrm{P}-\mathrm{C}}=17.1 \mathrm{~Hz}\right.$, $\left.-\left(\mathrm{CH}_{2}\right)-\mathrm{Ph}\right), 10.2\left(\mathrm{~d},{ }^{1} J_{\mathrm{P}-\mathrm{C}}=17.1 \mathrm{~Hz},-\mathrm{CH}_{3}\right)$.

Synthesis of $S P R^{\prime} R^{\prime \prime} R^{\prime \prime \prime}\left(\mathbf{4} \boldsymbol{a}^{\prime}-\boldsymbol{c}^{\prime}\right)$. Compound $\mathbf{4 a - c}(0.1 \mathrm{mmol}, 1 \mathrm{eq})$ were synthesized according to the previous procedure, dissolved in $10 \mathrm{~mL}$ of $\mathrm{n}$-pentane, respectively, added to a solution of sulfur $(0.1 \mathrm{mmol}, 3.2 \mathrm{mg}, 1 \mathrm{eq})$ in $10 \mathrm{~mL} \mathrm{n}$-pentane and stirred for $4 \mathrm{~h}$ at room temperature. The volume was reduced under reduced pressure and stored at $-30^{\circ} \mathrm{C}$. Colourless crystals of $4 \mathbf{a}^{\prime}-\mathbf{c}^{\prime}\left(\mathbf{a}: \mathrm{R}^{\prime}=\mathrm{Me}, \mathrm{R}^{\prime \prime}=\mathrm{iPr}, \mathrm{R}^{\prime \prime \prime}=\mathrm{Bnz}\right.$; $\mathbf{b}$ : $\mathrm{R}$ $\left.{ }^{\prime}=\mathrm{tBu}, \mathrm{R}^{\prime \prime}=\mathrm{Me}, \mathrm{R}^{\prime \prime \prime}=\mathrm{Bnz} ; \mathrm{c}: \mathrm{R}^{\prime}=\mathrm{Ph}, \mathrm{R}^{\prime \prime}=\mathrm{Me}, \mathrm{R}^{\prime \prime \prime}=\mathrm{Bnz}\right)$ were formed after 2 days. Yield: $4 \mathbf{a}^{\prime}: 16.0 \mathrm{mg}$ (0.089 mmol, 89\%), $\mathbf{4 b}^{\prime}: 17.5 \mathrm{mg}(0.08 \mathrm{mmol}, 80 \%), \mathbf{4} \mathbf{c}^{\prime}$ : $17.1 \mathrm{mg}(0.08 \mathrm{mmol}, 80 \%)$.

${ }^{1} \mathrm{H}$ NMR: 4a ${ }^{\prime}\left(\mathrm{C}_{6} \mathrm{D}_{6}, 293 \mathrm{~K}\right): \delta[\mathrm{ppm}]=7.05\left(\mathrm{~m}, 5 \mathrm{H},-\mathrm{CH}_{2}-\mathrm{C}_{6} \mathrm{H}_{5}\right), 2.89(\mathrm{t}, 1 \mathrm{H}$, $\left.{ }^{3} J_{\mathrm{P}-\mathrm{H}}=14.7 \mathrm{~Hz},-\mathrm{CH}_{2}-\mathrm{Ph}\right), 2.74\left(\mathrm{dd}, 1 \mathrm{H},{ }^{3} J_{\mathrm{P}-\mathrm{H}}=13.8 \mathrm{~Hz},{ }^{3} J_{\mathrm{H}-\mathrm{H}}=1.8 \mathrm{~Hz},-\mathrm{CH}_{2}-\right.$ $\mathrm{Ph}), 1.39\left(\mathrm{~m}, 1 \mathrm{H},-(\underline{\mathrm{C}} \mathrm{H})-\mathrm{CH}_{3}\right), 0.99\left(\mathrm{dd}, 3 \mathrm{H},{ }^{3} J_{\mathrm{P}-\mathrm{H}}=17.8 \mathrm{~Hz},{ }^{2} J_{\mathrm{H}-\mathrm{H}}=7.0 \mathrm{~Hz}\right.$, $\left.-(\mathrm{CH})-\left(\mathrm{CH}_{3}\right)_{2}\right), 0.97\left(\overline{\mathrm{d}}, 9 \mathrm{H},{ }^{2} J_{\mathrm{P}-\mathrm{H}}=11.9 \mathrm{~Hz},-\mathrm{CH}_{3}\right), 0.84\left(\mathrm{dd}, 3 \mathrm{H},{ }^{3} J_{\mathrm{P}-\mathrm{H}}=17.5 \mathrm{~Hz}\right.$, $\left.{ }^{2} J_{\mathrm{H}-\mathrm{H}}=6.9 \overline{\mathrm{Hz}},-(\mathrm{CH})-\left(\mathrm{CH}_{\underline{3}}\right)_{2}\right) ; 4 \mathbf{b}^{\prime}\left(\mathrm{C}_{6} \mathrm{D}_{6}, 293 \mathrm{~K}\right): \delta[\mathrm{ppm}]=7.27\left(\mathrm{~m}, 2 \mathrm{H},-\mathrm{CH}_{2}-\right.$ $\left.\mathrm{C}_{6} \mathrm{H}_{5}\right), 7.12\left(\mathrm{~m}, 3 \mathrm{H},-\mathrm{CH}_{2}-\mathrm{C}_{6} \mathrm{H}_{5}\right), 2.79\left(\mathrm{~m}, 2 \mathrm{H},-\mathrm{CH}_{2}-\mathrm{Ph}\right), 0.97(\mathrm{~d}, 3 \mathrm{H}$,

$\left.{ }^{2} J_{\mathrm{P}-\mathrm{H}}=11.8 \mathrm{~Hz},-\mathrm{CH}_{3}\right), 0.95\left(\mathrm{~d}, 9 \mathrm{H},{ }^{3} \mathrm{~J}_{\mathrm{P}-\mathrm{H}}=15.5 \mathrm{~Hz},-\mathrm{C}\left(\mathrm{CH}_{3}\right)_{3}\right) ; 4 \mathrm{c}^{\prime}\left(\mathrm{C}_{6} \mathrm{D}_{6}, 293 \mathrm{~K}\right)$ : $\delta[\mathrm{ppm}]=7.60(\mathrm{~m}, 2 \mathrm{H},-\mathrm{Ph}), 7.00(\mathrm{~m}, 6 \mathrm{H},-\mathrm{Ph}), 6.91(\mathrm{~m}, 2 \overline{\mathrm{H}},-\mathrm{Ph}), 3.01(\mathrm{~d}, 2 \mathrm{H}$, $\left.{ }^{2} J_{\mathrm{P}-\mathrm{H}}=14.1 \mathrm{~Hz},-\mathrm{CH}_{2}-\mathrm{Ph}\right), 1.39\left(\mathrm{~d}, 3 \mathrm{H},{ }^{2} J_{\mathrm{P}-\mathrm{H}}=12.7 \mathrm{~Hz},-\mathrm{CH}_{2}-\mathrm{Ph}\right)$

${ }^{31} \mathrm{P}\left\{{ }^{1} \mathrm{H}\right\}$ NMR: $4 \mathbf{a}^{\prime}\left(\mathrm{C}_{6} \mathrm{D}_{6}, 293 \mathrm{~K}\right): \delta[\mathrm{ppm}]=51.3(\mathrm{~s}) ; 4 \mathbf{b}^{\prime}\left(\mathrm{C}_{6} \mathrm{D}_{6}, 293 \mathrm{~K}\right): \delta$ $[\mathrm{ppm}]=58.6(\mathrm{~s}) ; 4 \mathrm{c}^{\prime}\left(\mathrm{C}_{6} \mathrm{D}_{6}, 293 \mathrm{~K}\right): \delta[\mathrm{ppm}]=38.0(\mathrm{~s})$

${ }^{31} \mathrm{P}$ NMR: $4 \mathbf{a}^{\prime}\left(\mathrm{C}_{6} \mathrm{D}_{6}, 293 \mathrm{~K}\right): \delta[\mathrm{ppm}]=51.3(\mathrm{~s}, \mathrm{br}) ; 4 \mathbf{b}^{\prime}\left(\mathrm{C}_{6} \mathrm{D}_{6}, 293 \mathrm{~K}\right): \delta$ $[\mathrm{ppm}]=58.6(\mathrm{~m}) ; 4 \mathbf{c}^{\prime}\left(\mathrm{C}_{6} \mathrm{D}_{6}, 293 \mathrm{~K}\right): \delta[\mathrm{ppm}]=38.0(\mathrm{~m})$.
${ }^{13} \mathrm{C}\left\{{ }^{1} \mathrm{H}\right\}$ NMR: 4a' $\left(\mathrm{C}_{6} \mathrm{D}_{6}, 293 \mathrm{~K}\right): \delta[\mathrm{ppm}]=132.7\left(\mathrm{~d},{ }^{2} \mathrm{~J}_{\mathrm{P}-\mathrm{C}}=7.9 \mathrm{~Hz}, \mathrm{Ph}\right), 129.7$ $\left(\mathrm{d},{ }^{3} J_{\mathrm{P}-\mathrm{C}}=4.9 \mathrm{~Hz}, \mathrm{Ph}\right), 128.2\left(\mathrm{~d},{ }^{4} J_{\mathrm{P}-\mathrm{C}}=2.8 \mathrm{~Hz}, \mathrm{Ph}\right), 126.8\left(\mathrm{~d},{ }^{3} J_{\mathrm{P}-\mathrm{C}}=3.3 \mathrm{~Hz}, \mathrm{Ph}\right)$ $39.4\left(\mathrm{~d},{ }^{1} J_{\mathrm{P}-\mathrm{C}}=45.1 \mathrm{~Hz},-\left(\mathrm{CH}_{2}\right)-\mathrm{Ph}\right), 28.7\left(\mathrm{~d},{ }^{1} J_{\mathrm{P}-\mathrm{C}}=52.3 \mathrm{~Hz},-(\mathrm{CH})-\left(\mathrm{CH}_{3}\right)_{2}\right), 15.6$ $\left(\mathrm{d},{ }^{2} J_{\mathrm{P}-\mathrm{C}}=21.3 \mathrm{~Hz},-(\mathrm{CH})-\left(\mathrm{CH}_{3}\right)_{2}\right), 15.5\left(\mathrm{~d},{ }^{1} J_{\mathrm{P}-\mathrm{C}}=52.5 \mathrm{~Hz},-\mathrm{CH}_{3} 15.3(\mathrm{~d}\right.$, $\left.{ }^{2} J_{\mathrm{P}-\mathrm{C}}=26.8 \mathrm{~Hz},-(\mathrm{CH})-\left(\mathrm{CH}_{3}\right)_{2}\right) ; 4 \mathbf{b}^{\prime}\left(\mathrm{C}_{6} \mathrm{D}_{6}, 293 \mathrm{~K}\right): \delta[\mathrm{ppm}]=132.9(\mathrm{~d}$, $\left.{ }^{2} J_{\mathrm{P}-\mathrm{C}}=7.8 \mathrm{~Hz}, \mathrm{Ph}\right), 130 . \overline{6}\left(\mathrm{~d},{ }^{3} J_{\mathrm{P}-\mathrm{C}}=5.7 \mathrm{~Hz}, \mathrm{Ph}\right), 127.1\left(\mathrm{~d},{ }^{5} J_{\mathrm{P}-\mathrm{C}}=2.9 \mathrm{~Hz}, \mathrm{Ph}\right)$, $127.1\left(\mathrm{~d},{ }^{4} J_{\mathrm{P}-\mathrm{C}}=3.2 \mathrm{~Hz}, \mathrm{Ph}\right), 36.1\left(\mathrm{~d},{ }^{1} J_{\mathrm{P}-\mathrm{C}}=43.1 \mathrm{~Hz},-\left(\mathrm{CH}_{2}\right)-\mathrm{Ph}\right), 33.3(\mathrm{~d}$, $\left.{ }^{1} J_{\mathrm{P}-\mathrm{C}}=49.4 \mathrm{~Hz},-\underline{\mathrm{C}}\left(\mathrm{CH}_{3}\right)_{3}\right), 24.6\left(\mathrm{~d},{ }^{2} J_{\mathrm{P}-\mathrm{C}}=1.4 \mathrm{~Hz},-\mathrm{C}\left(\underline{\mathrm{CH}}_{3}\right)_{3}\right), 13.4(\mathrm{~d}$, $\left.{ }^{1} J_{\mathrm{P}-\mathrm{C}}=50.8 \mathrm{~Hz},-\overline{\mathrm{C}} \mathrm{H}_{3}\right) ; 4 \mathbf{c c}^{\prime}\left(\mathrm{C}_{6} \mathrm{D}_{6}, 293 \mathrm{~K}\right): \delta[\mathrm{ppm}]=131.0\left(\mathrm{~d},{ }^{2} J_{\mathrm{P}-\mathrm{C}}=9.9 \mathrm{~Hz}, \mathrm{Ph}\right)$, $130.8\left(\mathrm{~d},{ }^{4} J_{\mathrm{P}-\mathrm{C}}=2.8 \mathrm{~Hz}, \mathrm{Ph}\right), 130.0\left(\mathrm{~d},{ }^{3} J_{\mathrm{P}-\mathrm{C}}=5.2 \mathrm{~Hz}, \mathrm{Ph}\right), 126.8\left(\mathrm{~d},{ }^{3} J_{\mathrm{P}-\mathrm{C}}=3.7 \mathrm{~Hz}\right.$, $\mathrm{Ph}), 43.8\left(\mathrm{~d},{ }^{1} J_{\mathrm{P}-\mathrm{C}}=49.0 \mathrm{~Hz},-\left(\mathrm{CH}_{2}\right)-\mathrm{Ph}\right), 18.9\left(\mathrm{~d},{ }^{1} J_{\mathrm{P}-\mathrm{C}}=57.3 \mathrm{~Hz},-\mathrm{C}\left(\mathrm{CH}_{3}\right)_{3}\right)$.

$4 a^{\prime}:$ EI-MS $\left(\mathrm{CH}_{2} \mathrm{Cl}_{2}\right)$ : $212.08\left(37 \%,[\mathrm{M}]^{+}\right), 91.05\left(100 \%[\mathrm{Bnz}]^{+}\right),-170.03(46 \%$

$\left.\left[\mathrm{M}-\mathrm{C}_{3} \mathrm{H}_{6}\right]^{+}\right)$.

$4 \mathbf{b}^{\prime}:$ GC-MS $\left(\mathrm{CH}_{2} \mathrm{Cl}_{2}\right): 226.09\left(20 \%,[\mathrm{M}]^{+}\right), 91.06\left(100 \%[\mathrm{Bnz}]^{+}\right), 170.03(44 \%$ $\left.\left[\mathrm{M}-{ }^{t} \mathrm{Bu}+\mathrm{H}\right]^{+}\right)$.

$4 \mathbf{c}^{\prime}:$ EI-MS $\left(\mathrm{CH}_{2} \mathrm{Cl}_{2}\right): 246.06\left(44 \%,[\mathrm{M}]^{+}\right), 155.01\left(100 \%[\mathrm{M}-\mathrm{Bnz}]^{+}\right), 91.06$ $\left(25 \%[\mathrm{Bnz}]^{+}\right)$.

Targeted synthesis of $[K(18 c 6)(t h f)]\left[C p^{*} \mathrm{Fe}\left(\eta^{4}-P_{4}\right)\right]$ (5). Compound $3 \mathrm{c}(0.2 \mathrm{mmol}$, $75.2 \mathrm{mg}, 1 \mathrm{eq}), \mathrm{KBnz}(0.2 \mathrm{mmol}, 26.0 \mathrm{mg}, 1 \mathrm{eq})$ and 18 -crown-6 $(0.2 \mathrm{mmol}$, $52.9 \mathrm{mg}, 1 \mathrm{eq})$ were dissolved separately in THF and cooled to $-80^{\circ} \mathrm{C}$. The potassium benzyl solution is added to compound 3c, stirred for $2 \mathrm{~min}$ and $18 \mathrm{c} 6$ is added afterwards. The mixture was allowed to stir overnight and reach room temperature. The solvent of the resulting brown solution was removed in vacuo The by-product $\mathrm{PMe}_{2} \mathrm{Bnz}$ was removed by washing the oily residue three times with $5 \mathrm{~mL}$ of $n$-pentane, resulting a greenish powder, which was dissolved in THF and layered with $n$-hexane. The solution was stored at $-30{ }^{\circ} \mathrm{C}$ and compound 5 was isolated as highly air-sensitive green/turquoise plates/blocks after 1 week. Yield: $111.9 \mathrm{mg}(0.16 \mathrm{mmol}, 81 \%) .{ }^{1} \mathrm{H}$ NMR (THF-d, $\left.293 \mathrm{~K}\right): \delta[\mathrm{ppm}]=3.73(\mathrm{~s}$, $26 \mathrm{H}, 18$-crown-6), $2.26\left(\mathrm{~s}, 15 \mathrm{H}, \mathrm{C}_{5}\left(\mathrm{CH}_{3}\right)_{5}\right) .{ }^{31} \mathrm{P}\left\{{ }^{1} \mathrm{H}\right\}$ NMR $($ THF-d $8,293 \mathrm{~K}): \delta$ $[\mathrm{ppm}]=118.9(\mathrm{~s}),{ }^{31} \mathrm{P}$ NMR $\left(\mathrm{THF}-\mathrm{d}_{8}, 293 \mathrm{~K}\right): \delta[\mathrm{ppm}]=118.9(\mathrm{~s})$. ESI-MS (anion, DME): $m / z=314.95\left(100 \%,[\mathrm{M}]^{-}\right)$; analysis (calcd., found for $\mathrm{C}_{22} \mathrm{H}_{39} \mathrm{FeP}_{4} \mathrm{KO}_{6}$. THF $)_{0.75}$ C $(44.65,44.28), \mathrm{H}(6.74,6.67)$.

Synthesis of $\mathrm{PMe}{ }_{2} \mathrm{Bnz}$ and regeneration of $\left[\mathrm{Cp} * \mathrm{Fe}\left(\eta^{5}-\mathrm{P}_{5}\right)\right]$ (1) in a cyclic process. Compound $1(3.00 \mathrm{mmol}, 1.04 \mathrm{~g}, 1 \mathrm{eq})$ was dissolved in $100 \mathrm{~mL}$ tetraglyme, $1.88 \mathrm{~mL}$ of a 1.6 molar solution of $\mathrm{MeLi}(3.00 \mathrm{mmol}, 1 \mathrm{eq})$ in $\mathrm{Et}_{2} \mathrm{O}$ was added and the resulting solution was allowed to stir for $5 \mathrm{~min}$. To the reaction mixture, $2.80 \mathrm{~mL}$ of a 1.07 molar solution of $\mathrm{MeI}(3.00 \mathrm{mmol}, 1 \mathrm{eq})$ in $\mathrm{Et}_{2} \mathrm{O}$ was slowly added at room temperature and stirred for $5 \mathrm{~min}$. The diethylether of the stock solutions was removed under reduced pressure. The reaction mixture was cooled to $-30^{\circ} \mathrm{C}$, a solution of $\mathrm{KBnz}(3.00 \mathrm{mmol}, 390.7 \mathrm{mg}, 1 \mathrm{eq})$ in $50 \mathrm{~mL}$ tetraglyme was added and the reaction was stirred for $30 \mathrm{~min}$. The cooling bath was removed and the phosphine $\mathrm{PMe}_{2} \mathrm{Bnz}$ was distilled off under reduced pressure $\left(1 \times 10^{-3} \mathrm{mbar}\right.$, $\left.55^{\circ} \mathrm{C}\right)$. White phosphorus $(3.00 \mathrm{mmol}, 371.7 \mathrm{mg}, 1 \mathrm{eq})$ was added to the remaining solution and the reaction mixture was heated under reflux for $1 \mathrm{~h}$ at $275^{\circ} \mathrm{C}$. The described steps were repeated two more times. The starting material $\mathbf{1}$ was isolated after column chromatographic workup (silica gel, $n$-hexane, $20 \times 2 \mathrm{~cm}$ ) in overall $69 \%$ yield $\left(2.07 \mathrm{mmol}, 2.07 \mathrm{~g}\right.$ ) (Supplementary Fig. 66). The phosphine $\mathrm{PMe}_{2} \mathrm{Bnz}$ was isolated as a pyrophoric colourless liquid in an overall yield of $79 \%(2.37 \mathrm{mmol}$ $315.0 \mathrm{mg}$ ) (see Supplementary Fig. 67, Supplementary Table 40).

\section{Data availability}

The X-ray crystallographic coordinates for structures reported in this study have been deposited at the Cambridge Crystallographic Data Centre (CCDC), under deposition numbers CCDC-2041977 (2c), CCDC-2041978 (2d), CCDC-2083624 (2e), CCDC2041979 (3a), CCDC-2041980 (3b), CCDC-2083625 (3c), CCDC-2083626 (3d), CCDC2041981 (3e), CCDC-2083627 (3f), CCDC-2083628 (4a'), CCDC-2083629 (4b'), CCDC$2083630\left(4 \mathbf{c}^{\prime}\right)$ and CCDC-2083631 (5). These data can be obtained free of charge from The Cambridge Crystallographic Data Centre via www.ccdc.cam.ac.uk/data_request/cif. All other data are available in the main text or in the Supplementary Information.

Received: 1 July 2021; Accepted: 13 September 2021; Published online: 01 October 2021

\section{References}

1. Montchamp, J. L. Phosphinate chemistry in the 21st century: a viable alternative to the use of phosphorus trichloride in organophosphorus synthesis. Acc. Chem. Res. 47, 77-87 (2014).

2. Tang, W. \& Zhang, X. New chiral phosphorus ligands for enantioselective hydrogenation. Chem. Rev. 103, 3029-3069 (2003).

3. Karl, D. M. Phosphorus the staff of life. Nature 406, 31-33 (2000).

4. Kamer, P. C. J. \& Leeuwen, P. W. N. van. Phosphorus(III)Ligands in Homogeneous Catalysis: Design and Synthesis (Wiley, 2012). 
5. Pignolet, L. Homogeneous Catalysis with Metal Phosphine Complexes. Modern Inorganic Chemistry (Springer US, 1983).

6. Teichert, J. F. Homogeneous Hydrogenation with Non-Precious Catalysts (Wiley, 2019).

7. Guo, H., Fan, Y. C., Sun, Z., Wu, Y. \& Kwon, O. Phosphine organocatalysis. Chem. Rev. 118, 10049-10293 (2018).

8. Osborn, J. A., Wilkinson, G. \& Mrowca, J. J. In Inorganic Syntheses 67-71 (John Wiley \& Sons, Ltd, 1967).

9. Märkl, G. Heterocycles containing phosphorus. Angew. Chem. - Int. Ed. 4, 1023-1038 (1965).

10. Baudler, M. et al. ${ }^{\mathrm{t}} \mathrm{Bu}_{6} \mathrm{P}_{8}$ and ${ }^{\mathrm{t}} \mathrm{Bu}_{6} \mathrm{As}_{8}-$ two new element-homologous bicyclic compounds of different. Struct. Angew. Chem. Int. Ed. Engl. 20, 406-408 (1981).

11. Gómez-Ruiz, S. \& Hey-Hawkins, E. The unusual coordination chemistry of phosphorus-rich linear and cyclic oligophosphanide anions. Coord. Chem. Rev. 255, 1360-1386 (2011).

12. Musina, E. I., Balueva, A. S. \& Karasik, A. A. In Organophosphorus Chemistry Vol. 48, 1-439 (The Royal Society of Chemistry, 2019).

13. Hey-Hawkins, E. \& Karasik, A. A. In Category 5, Compounds with One Saturated Carbon Heteroatom Bond (eds. Mathey \& Trost) Vol. 42, 71-108 (Georg Thieme Verlag, 2009).

14. Lühr, S., Holz, J. \& Börner, A. The synthesis of chiral phosphorus ligands for use in homogeneous metal catalysis. ChemCatChem 3, 1708-1730 (2011).

15. L. Clevenger, A. M., Stolley, R., Aderibigbe, J. \& Louie, J. Trends in the usage of bidentate phosphines as ligands in nickel catalysis. Chem. Rev. 120, 6124-6196 (2020).

16. The Nobel Prize in Chemistry 2001. https://www.nobelprize.org/prizes/ chemistry/2001/summary/ (2001).

17. Gusarova, N. K. \& Trofimov, B. A. Organophosphorus chemistry based on elemental phosphorus: advances and horizons. Russ. Chem. Rev. 89, 225-249 (2020).

18. Bettermann, G., Krause, W., Riess, G. \& Hofmann, T. Phosphorus Compounds, Inorganic, Ullmann's Encyclopedia of Industrial Chemistry (Wiley, 2012).

19. Svara, J., Weferling, N. \& Hofmann, T. Phosphorus Compounds, Organic, Ullmann's Encyclopedia of Industrial Chemistry (Wiley, 2006).

20. Geeson, M. B. \& Cummins, C. C. Phosphoric acid as a precursor to chemicals traditionally synthesized from white phosphorus. Science 359, 1383-1385 (2018).

21. Geeson, M. B. \& Cummins, C. C. Let's make white phosphorus obsolete. ACS Cent. Sci. 6, 848-860 (2020)

22. Cossairt, B. M. \& Cummins, C. C. Radical synthesis of trialkyl, triaryl, trisilyl and tristannyl phosphines from $\mathrm{P}_{4}$. N. J. Chem. 34, 1533-1536 (2010).

23. Yakhvarov, D. G., Gorbachuk, E. V., Kagirov, R. M. \& Sinyashin, O. G. Electrochemical reactions of white phosphorus. Russ. Chem. Bull. 61, 1300-1312 (2012).

24. Ghosh, S. K., Cummins, C. C. \& Gladysz, J. A. A direct route from white phosphorus and fluorous alkyl and aryl iodides to the corresponding trialkyland triarylphosphines. Org. Chem. Front. 5, 3421-3429 (2018).

25. Arockiam, P. B. et al. Versatile visible-light-driven synthesis of asymmetrical phosphines and phosphonium salts. Chem. Eur. J. 26, 16374-16382 (2020).

26. Lennert, U. et al. Direct catalytic transformation of white phosphorus into arylphosphines and phosphonium salts. Nat. Catal. 2, 1101-1106 (2019).

27. Scott, D. J., Cammarata, J., Schimpf, M. \& Wolf, R. Synthesis of monophosphines directly from white phosphorus. Nat. Chem. 13, 458-464 (2021).

28. Mädl, E. et al. Functionalization of a cyclo- $\mathrm{P}_{5}$ ligand by main-group element nucleophiles. Angew. Chem. Int. Ed. 53, 7643-7646 (2014).

29. Pyykkö, P. \& Atsumi, M. Molecular single-bond covalent radii for elements 1-118. Chem. Eur. J. 15, 186-197 (2009).

30. Pyykkö, P. \& Atsumi, M. Molecular double-bond covalent radii for elements Li-E112. Chem. Eur. J. 15, 12770-12779 (2009).

31. Riegel, S. D., Burford, N., Lumsden, M. D. \& Decken, A. Synthesis and characterization of elusive cyclo-di- and -tri-phosphino-1,3-diphosphonium salts: fundamental frameworks in catena-organophosphorus chemistry. Chem. Commun. 793, 4668-4670 (2007).

32. Butovskiy, M. V. et al. Ferrocene and pentaphosphaferrocene: a comparative study regarding redox chemistry. Angew. Chem. Int. Ed. 52, 2972-2976 (2013).

33. Chakraborty, U. et al. Mono- and dinuclear tetraphosphabutadiene ferrate anions. Dalt. Trans. 47, 3693-3697 (2018).

34. Hoidn, C. M., Maier, T. M., Trabitsch, K., Weigand, J. J. \& Wolf, R. [3+2] Fragmentation of a Pentaphosphido Ligand by Cyanide. Angew. Chem. Int. Ed. 58, 18931-18936 (2019).

35. Mandla, K. A., Neville, M. L., Moore, C. E., Rheingold, A. L. \& Figueroa, J. S. Dianionic mononuclear cyclo- $\mathrm{P}_{4}$ complexes of zero-valent molybdenum: coordination of the cyclo- $\mathrm{P}_{4}$ dianion in the absence of intramolecular charge transfer. Angew. Chem. Int. Ed. 58, 15329-15333 (2019).
36. Baudler, M. \& Etzbach, T. Beiträge zur Chemie des Phosphors, 215. Einfache Darstellung des pentaphosphacyclopentadienid-Ions,cyclo- $\mathrm{P}_{5}{ }^{-}$, durch Abbau von rotem Phosphor mit Kaliumdihydrogenphosphid. Chem. Ber. 124, 1159-1160 (1991)

37. Miluykov, V. A., Sinyashin, O. G., Scherer, O. J. \& Hey-Hawkins, E. Reactions of the pentaphospholide anion with half-sandwich complexes of iron: a new route to pentaphosphaferrocenes. Mendeleev Commun. 12, 1-2 (2002).

38. Frisch, M. J. et al. G16_D09. Gaussian 16, Revision D.09 (Gaussian, Inc., 2016).

39. Becke, A. D. Density - functional thermochemistry. III. The role of exact exchange density-functional thermochemistry. III. The role of exact exchange. J. Chern. Phys. 98, 5648-5652 (2005).

40. Vosko, S. H., Wilk, L. \& Nusair, M. Accurate spin-dependent electron liquid correlation energies for local spin density calculations: a critical analysis. Can. J. Phys. 58, 1200-1211 (1980).

41. Lee, C., Yang, W. \& Parr, R. G. Development of the Colle-Salvetti correlationenergy formula into a functional of the electron density. Phys. Rev. B 37, 785-789 (1988).

42. Stephen, P. J., Devlin, F. J., Chabalowski, C. F. \& Frisch, M. J. Ab initio calculation of vibrational absorption. J. Phys. Chem. 98, 11623-11627 (1994).

43. Weigend, F. \& Ahlrichs, R. Balanced basis sets of split valence, triple zeta valence and quadruple zeta valence quality for $\mathrm{H}$ to $\mathrm{Rn}$ : Design and assessment of accuracy. Phys. Chem. Chem. Phys. 7, 3297-3305 (2005)

44. Tomasi, J., Mennucci, B. \& Cammi, R. Quantum mechanical continuum solvation models. Chem. Rev. 105, 2999-3093 (2005).

45. Grimme, S., Ehrlich, S. \& Goerigk, L. Effect of the damping function in dispersion corrected density functional theory. J. Comput. Chem. 32, 1456-1465 (2011)

46. Bourhis, L. J., Dolomanov, O. V., Gildea, R. J., Howard, J. A. K. \& Puschmann, H. Olex2: a complete structure solution, refinement and anlysis program. J. Appl. Crystallogr. 42, 339-341 (2009).

47. Sheldrick, G. M. SHELXT-Integrated space-group and crystal-structure determination. Acta Crystallogr. Sect. A 71, 3-8 (2015).

48. Sheldrick, G. M. Crystal structure refinement with ShelXL. Acta Crystallogr. Sect. C. 71, 3-8 (2015).

49. Scherer, O. J., Brück, T. \& Wolmershäuser, G. Pentaphosphametallocene. Chem. Ber. 121, 935-938 (1988).

50. Antoine, E. S. S., Lochmann, L. \& Trekoval, J. Li-K Exchange in alkyllithium/ pottasium t-pentoxides systems XIV. J. Organomet. Chem. 326, 1-7 (1987).

\section{Acknowledgements}

This work was supported by the Deutsche Forschungsgemeinschaft within the project Sche 384/38-1. The authors thank J. Gramüller (group of R. Gschwind, University of Regensburg) for the low-temperature NMR experiment. S.R. is grateful to the Studien stiftung des Deutschen Volkes and M.P. to the Fonds der Chemischen Industrie for their PhD fellowships.

\section{Author contributions}

S.R., E.M., F.R. and M.P. conceived the experiments. G.B. performed the computational studies. M.Se. analysed and revised the X-ray data; S.R., G.B. and M.Sch. wrote the manuscript. M.Sch. directed and coordinated the research.

\section{Funding}

Open Access funding enabled and organized by Projekt DEAL.

\section{Competing interests}

The authors declare no competing interests.

\section{Additional information}

Supplementary information The online version contains supplementary material available at https://doi.org/10.1038/s41467-021-26002-7.

Correspondence and requests for materials should be addressed to Manfred Scheer.

Peer review information Nature Communications thanks Abel de Cózar and the other, anonymous, reviewer(s) for their contribution to the peer review of this work.

Reprints and permission information is available at http://www.nature.com/reprints

Publisher's note Springer Nature remains neutral with regard to jurisdictional claims in published maps and institutional affiliations. 
(c) (i) Open Access This article is licensed under a Creative Commons Attribution 4.0 International License, which permits use, sharing, adaptation, distribution and reproduction in any medium or format, as long as you give appropriate credit to the original author(s) and the source, provide a link to the Creative Commons license, and indicate if changes were made. The images or other third party material in this article are included in the article's Creative Commons license, unless indicated otherwise in a credit line to the material. If material is not included in the article's Creative Commons license and your intended use is not permitted by statutory regulation or exceeds the permitted use, you will need to obtain permission directly from the copyright holder. To view a copy of this license, visit http://creativecommons.org/ licenses/by/4.0/.

(C) The Author(s) 2021 